Z. Dt. Ges. Geowiss. (German J. Geol.), 169 (3), p. 389-411, 9 figs., 1 table

\title{
Multiphase fossil normal faults as geothermal exploration targets in the Western Bavarian Molasse Basin: Case study Mauerstetten
}

\author{
Elena Mraz¹, Inga Moeck², Silke Bissmann³ \& Stephan Hild*
}

\begin{abstract}
Mraz, E., Moeck, I., Bissmann, S. \& Hild, S. (2018): Multiphase fossil normal faults as geothermal exploration targets in the Western Bavarian Molasse Basin: Case study Mauerstetten. - Z. Dt. Ges. Geowiss., 169: 389-411, Stuttgart.

Abstract: The Bavarian Molasse Basin represents a peripheral foreland basin hosting abundant hydrothermal resources in 3-5 km deep Upper Jurassic carbonate rocks. Faults and facies play a major role in targeting production wells; however the kinematic evolution of fault zones and the classification of carbonate facies of the Upper Jurassic are still debated. At the geothermal prospect Mauerstetten in the Western Bavarian Molasse Basin, a geothermal well and a side track are drilled along and about $650 \mathrm{~m}$ off an ENE-WSW striking normal fault. A stratigraphy related fault throw analysis of six 2D seismic sections crossing this fault evidences multiphase normal faulting from Cretaceous to Upper Miocene with a major activity phase in the Oligocene. This fault, inactive since Upper Miocene, is presumably a fossil normal fault in the present-day stress field that has a maximum horizontal stress direction in $\mathrm{N}-\mathrm{S}$. Analysis of carbonate facies by thin section petrography of drill cuttings and geophysical borehole logs lead to two major conclusions: (i) the reservoir rock represents low permeable platform limestones, reef detritus and dolostones of the Franconian facies, and (ii) the fault consists of multiple normal faulting steps with higher permeability than in intact rock. This observation suggests a fracture controlled reservoir with permeable damage zones in a tight rock mass along reactivated normal faults.
\end{abstract}

Keywords: structural seismic interpretation, geothermal exploration, Western Molasse Basin, fault zone analysis, carbonate facies, foreland basins, fault throw analysis, thin section analysis

\section{Introduction}

Faults and facies of the rocks play a major role in reservoir exploration of carbonate reservoirs. Critical questions are addressed to the hydraulic properties of faults and their ability to channel fluids while matrix properties are interactively affected by sediment facies, karst evolution, pressure solution, early and late diagenetic processes, metasomatic dolomitisation and burial-related changes in diagenetic grade. The different response of faults to palaeostress regimes causes open (mechanically or secondarily opened by dissolution), cement-sealed (dissolution and precipitation), kaciritic cohesionless, tectonoclastic (cataclastic) lithified, authigenic clay mineral or fault gouge-filled, and discretely decollated or dispersedly brecciated, fossilised or migrationactive fractures. In carbonate reservoirs, a diagenetic replacement of dolomite in low permeable limestone can create barriers (Vandeginste et al. 2013) or the replacement of limestone by hydrothermal dolomite with a high intercrystal- line porosity may form a preferential conduit for fluids (e.g. Smith 2006). The fault structure is thus a strong controlling factor on the hydrostatic, hydro-pressured (gas over-pressured), hydrothermal setting of the fluids (volatiles) involved.

In the Bavarian Molasse Basin, faults serve as drilling targets in geothermal exploration of the Upper Jurassic carbonates. Faults in foreland basins such as the Molasse Basin undergo a complex history from pre-foreland basin settings related to lithospheric stretching accompanied by burial subsidence and thermal contraction of the cooling lithosphere to foreland basin evolution by flexural lithospheric bending and local extension in response to the tectonic load of the propagating orogenic front onto the basin. When the foreland basin is incorporated into the fold and thrust belt, and subsequently the fold-thrust front induces thrusting on the depocentre environment, a consecutive fault inversion in external parts and basin inversion at the front of the orogenic basal thrust will be formed. Brittle tectonic structures may

\footnotetext{
*Addresses of the authors:

${ }^{1}$ Technische Universität München, Arcisstr. 21, 80333 Munich, Germany (e.mraz@tum.de)

${ }^{2}$ Leibniz Institute for Applied Geophysics, Stilleweg 2, 30655 Hanover, Germany

${ }^{3}$ DMT, Am Technologiepark, Essen, Germany

${ }^{4}$ Exorka, Bavariafilmplatz, Grünwald-Munich, Germany; now at: Ingenieurbüro für Bauwesen und Geotechnik GmbH, Thaneller Str. 13, 86956 Schongau, Germany
} 


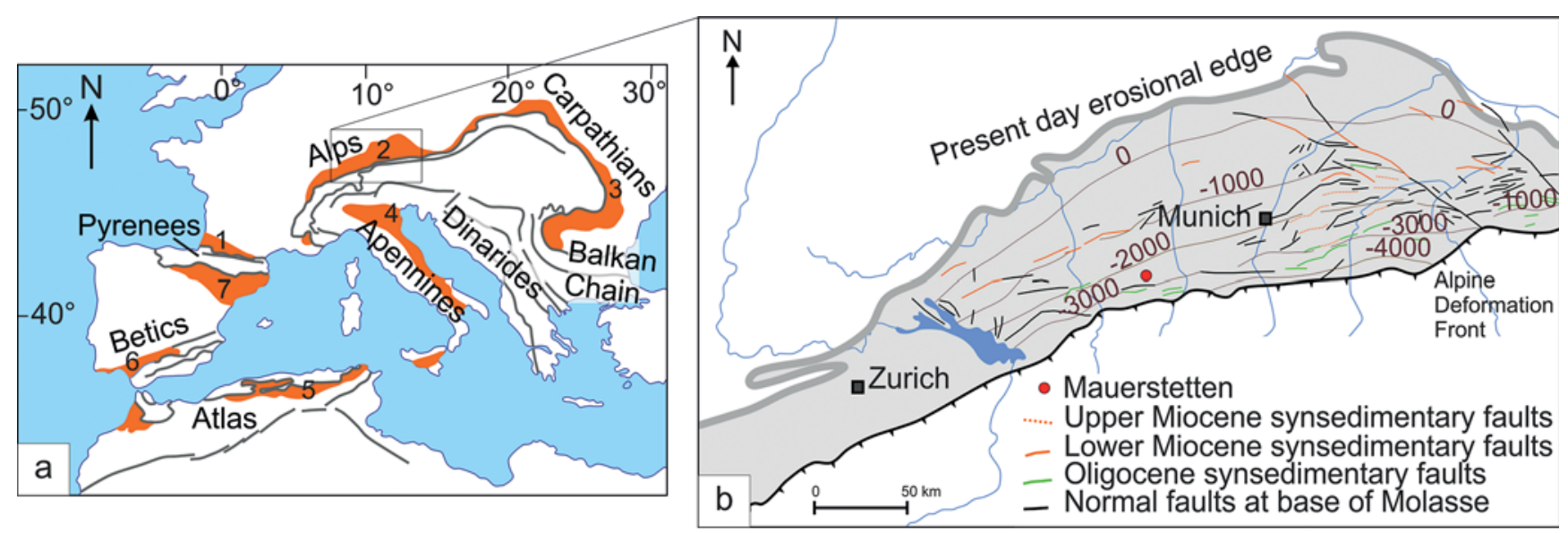

Fig. 1: The Bavarian Molasse Basin as one of seven Alpine foreland basins in Europe. (a) The seven Alpine foreland basins with $1=$ Aquitaine Basin, 2 = Molasse Basin, 3 = Carpathian Basin, $4=$ Apenninic basins and Po Basin, 5 = Atlas Basin, $6=$ North Bethic Basin, $7=$ South Pyrenean and Ebro Basin (modified from Allen et al. 1986). (b) Depth of the base of the Tertiary molasse sediments, the Tertiary fault pattern and the position of the well Mauerstetten in the Bavarian Molasse Basin (modified from Bachmann \& Mueller 1992).

include all styles of normal faulting as well as wrench faulting systems during foreland basin formation prior to reverse faulting at different late stages of the evolving basin depending of the geodynamic changes in the orogenic hinterland. During flexural rollback faults respond to the orogenic load on the foreland basin by extensional and compressional structures, both are synchronously possible (Hsü \& Briegel 1991).

The Bavarian Molasse Basin is one of seven Alpine foreland basins in Europe (Fig. 1a) and exhibits more than seven decades in exploration history. The three to five kilometre deep Upper Jurassic, so-called Malm in the geothermal community, of the Molasse Basin (Fig. 1b) is explored recently for geothermal and - to a minor degree - in the last decades for hydrocarbon resources. In the Bavarian, BadenWuerttemberg and Austrian basin parts, exploration for hydrocarbons started much earlier in the 1950s and resulted in seismic surveying and several hundred wells in the mainly undisturbed non-faulted Eocene and Miocene Molasse sediments while the Mesozoic substratum was less explored (Bachmann et al. 1987, Hinsch 2013). Specifically to the $\mathrm{SE}$, in the area between the Lake Constance and the studied drilling site Mauerstetten (Fig. 1b), the hydrocarbon potential is low and most reservoirs are non-productive independent of the maturity stage of the hydrocarbon source drock.

In the 1970 s to 1980 s the pre-Tertiary strata were studied for deep groundwater resources (Lemcke 1976) and for sedimentary and tectonic cycles (Lemcke 1973, Lange 1981, Bachmann et al. 1987). With the scientific seismic profile TRANSALP, the general deep structural pattern was identified in the eastern part of the basin consisting of synthetic (south-dipping) and antithetic (north-dipping) normal faults with Alpine strike direction dipping under the folded Molasse sediments close to the frontal fault of the Alpine fold and thrust belt (Lüschen et al. 2006). Seismic and well data show that the Variscan basement, Permo-Carboniferous,
Mesozoic and part of the Tertiary strata extend for at least $50 \mathrm{~km}$ underneath the nappes of the Alps. Below the folded Molasse sediments a crustal thickening toward the south of $10 \mathrm{~km}$ is evident (TRANSALP Working Group 2002, Lammerer et al. 2008), increasing again below the front of the Northern Calcareous Alps.

The Upper Jurassic deposits in particular are well studied for facies types (Kott 1989, Meyer \& Schmidt-Kaler 1996, Koch et al. 2010), karst formation (e.g. Seiler 1999), hydraulic and hydrochemical properties (Stober et al. 2013/14, Birner et al. 2012), diagenesis and dolomitisation (e.g. Michel 1999, Reinhold 1996, Liedmann 1992), palaeontology including microfossils and palaeogeography (e.g. Pomoni-Papaioannou et al. 1989) in outcropping sections of the Franconian and Swabian Alp. The subsurface Upper Jurassic carbonates of the Molasse Basin got recently into the focus of new interest when geothermal exploration started in the 2000 s in Bavaria searching for hydrothermal resources. With this renewed interest in the Upper Jurassic strata, open questions address physicochemical properties of different rock types, reservoir quality, the impact of faults on deep hydrogeology, fluid flow, discrimination of meteoric advective and deep thermal convective cycles, rock-water interaction and cement precipitation as well as dolomitisation and karstification processes with the ultimate goal to determine optimal drilling targets for geothermal production wells.

Information from already drilled deep geothermal boreholes in the central and eastern Bavarian Molasse Basin indicates most prospective sites in the vicinity of faults and carbonate rocks with high matrix porosity (Lüschen et al. 2011). It is generally known from fractured carbonate reservoirs that a cluster of faults channelling fluids and an enhanced matrix porosity increases the storage capacity for fluids thus leading to favourable reservoir rock qualities (Lian \& Ma 2012). In contrast to lithofacies changes and the occurrence of high porosity domains, faults can be reliably detected in the dataset of seismic sections during green field explora- 
tion, i.e. before drilling without well-log and seismic correlation. Thus, the characterisation of faults, the better knowledge about their kinematic and diagenetic evolution together with the better understanding of synkinematic processes controlling permeability structures obtain a primary role in exploration.

Faults in the Molasse Basin may have experienced a complex kinematic and diagenetic history, beginning with the fault formation, followed by the reactivation during different geodynamic stages from pre- to post-orogenic cycles and concluding with the exhumation and erosion exposure of the foreland. Hitherto, the normal faults of the Upper Jurassic formations have been geometrically described as synand antithetic faults partly overprinted by wrench tectonics (Bachmann et al. 1982, Bachmann et al. 1987, Lüschen et al. 2006) but their detailed tectono-genetic evolution is poorly understood (e.g. Budach et al. 2017). Cacace et al. (2013) mention the paradox of this normal fault-strike and dip because the faulting style does not reflect the present-day stress field, having possibly some effects on hydraulic properties. Effectively the impact of these faults on deep fluid flow, thermal and permeability structure is only preliminary discussed (Krämer 2009) and not well defined yet. If the time of formation of tectonic structures, their main displacement chronology and reactivation age during late orogeny are known, a prediction of thermo-diagenetic processes is possible and gives a better basis for modelling changes in porosity, permeability, compaction, hydrostatic and lithostatic pressures, and grade of rock-water interaction (solution and precipitation processes). All these factors and processes have to be included in a better prediction of reservoir quality and storage capacity. However, first of all the structural history has to be elucidated.

Therefore, this article addresses the question on reactivation episodes of normal faults rooting from the Upper Jurassic of the Bavarian Molasse Basin. The elementary focus relates to the formation time and the time spans of a potential tectonic reactivation. In cases of a detected reactivation it is important to know how faults were reactivated and giving implication on the fault kinematic history according to their ability to channel fluids. In a case study at the geothermal prospect Mauerstetten in the southwestern Bavarian Molasse Basin, six 2D seismic sections were structurally re-interpreted by a stratigraphy-based fault throw analysis to identify possible multiple faulting phases at certain periods related to Alpine geodynamic events. This analysis is completed by the detailed analysis of drill cuttings from the Mauerstetten wells (Fig. 1b) by thin section petrography and carbonate facies classification. The results of the structural and facies study are correlated with well log and hydraulic well data to constrain the factors controlling permeability in this part of the carbonate reservoir.

\section{The fault pattern in the western Molasse Basin}

The Bavarian Molasse Basin is a classical peripheral foreland basin skirting the central European Alpine fold-thrust belt with a characteristic asymmetrical wedge-shaped depocentre. The basin is part of the North Alpine Foreland Basin that extends from the Haute Savoy (France) in the west through Switzerland, Baden-Wuerttemberg and Bavaria to the Linz-Vienna area in Lower Austria in the east (Kuhlemann \& Kempf 2002), a distance of approximately $700 \mathrm{~km}$ (Homewood et al. 1986; Fig. 1). As the unfolded external foredeep of the Alps, the Molasse Basin widens substantially to the east with a maximum present-day width of about $150 \mathrm{~km}$ in southeast Germany (Lemcke 1988, Schmid et al. 2008). The basin fill of predominantly clastic Tertiary sediments is primarily the debris of the rising Alps and is referred to as Molasse which gives the basin its name reflecting its last basin stage as an orogenic foredeep. The Molasse Basin and its substratum underwent four major evolutionary stages, termed as syn-rift (Permo-Carboniferous), epicontinental (Triassic to Middle Jurassic), passive margin (Middle Jurassic to Late Cretaceous-Palaeocene) and Alpine foredeep (Oligocene to Pliocene), illustrated in an updated standard stratigraphic profile of the basin (Fig. 2). Taking into account slight interpretation differences the tectono-genetic evolution is according to Nachtmann \& Wagner (1987), Roeder \& Bachmann (1996) and Kuhlemann \& Kempf (2002). At the basis of the Molasse sediments (Oligocene to Miocene) a large hiatus is testifying to a basal unconformity evolving from the Helvetic European shelf domain to the Molasse Basin (Schmid et al. 1996, 2008) from the south in the Palaeocene to the north in the Oligocene (Chattian). The Molasse is underlain by $500-1,000 \mathrm{~m}$ thick Mesozoic platform sediments that represent the passive margin basin of the Neotethys (Stampfli \& Borel 2004). The predominantly mid to late Jurassic carbonate beds are deposited on Variscan basement that is locally segmented by Permo-Carboniferous troughs containing clastic sediments of largely unknown thickness and composition (Lemcke 1988, Lüschen et al. 2011). The deposition of marine and freshwater molasse from Late Eocene to Late Miocene represents the foreland basin period where sedimentation was controlled by erosion and uplift cycles of the Alpine fold and thrust belt (Lemcke 1977, Kuhlemann \& Kempf 2002).

The prospect Mauerstetten is located about $15 \mathrm{~km}$ north of the frontal fault of the folded Subalpine Molasse representing the northbound of the folded Tertiary erosive products delivered from the uplifting Alps (Bayerischer Geothermieatlas 2010), the Miocene external thrust belt (Schmid et al. 2008; Fig. 1b). North of the exposed frontal fault of the Subalpine Molasse subsurface gently southward dipping faults, known as blind reverse faults, are frequently located in mid to late Tertiary strata (Bachmann et al. 1987, Krämer 2009). This reverse faulting pattern might have overprinted an older normal faulting pattern and may indicate a zonation of different stress regimes with possibly a reverse faulting stress regime in the Upper Tertiary sediments and close to 


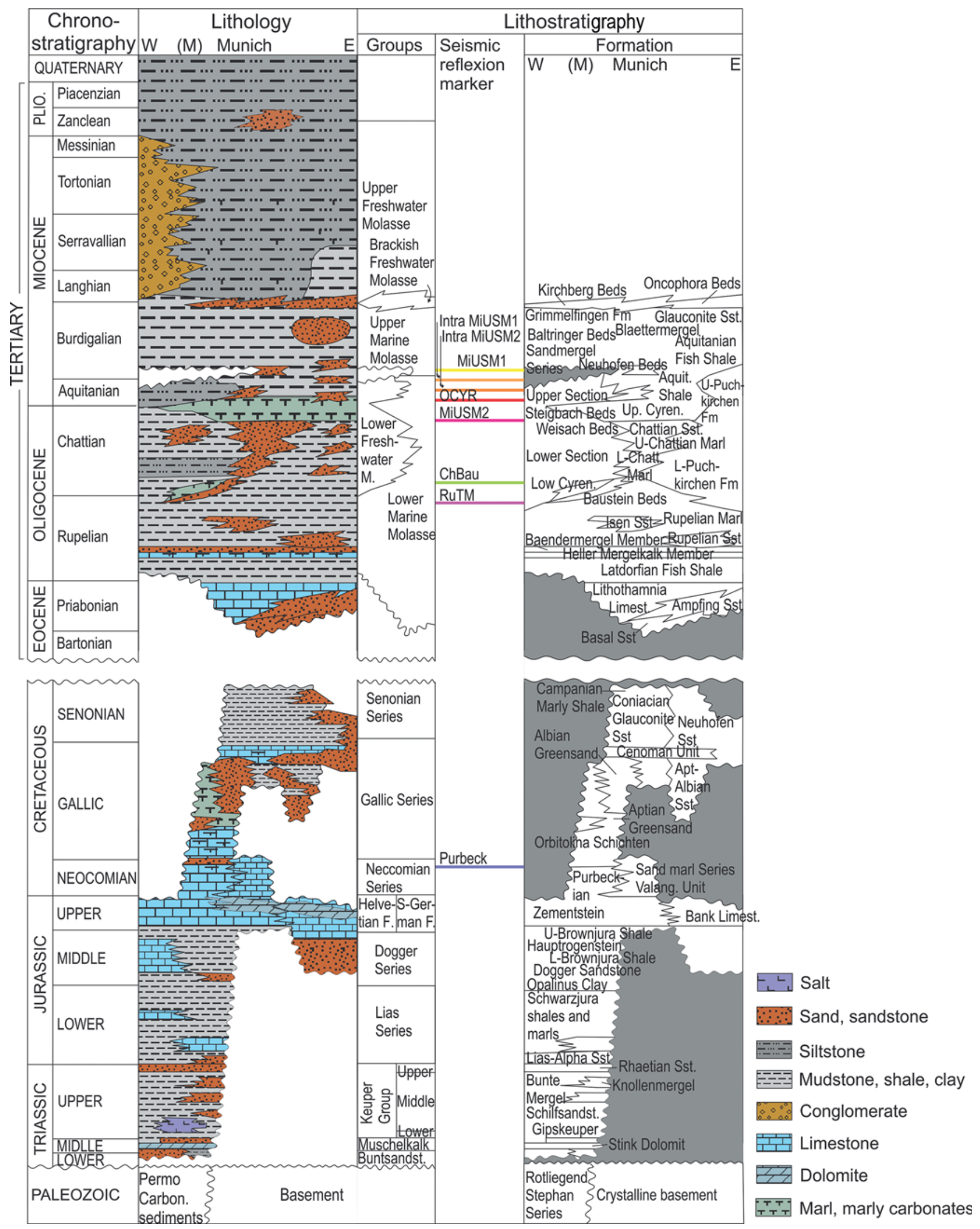

Fig. 2: Standard stratigraphic profile of the Bavarian Molasse Basin from east to west crossing the Munich area. The "(M)" indicates the position of the well Mauerstetten. Results from the well are incorporated into the stratigraphic profile (e.g. absence of the Lithothamnia Formation). Compiled and modified from Bachmann \& Mueller (1992), Sissingh (1997) and Kuhlemann \& Kempf (2002). 
the Alpine frontal fault, and a strike-slip to normal faulting stress regime in the Mesozoic (Reinecker et al. 2010, Cacace et al. 2013). Strike-slip faulting is suggested by Krämer (2009) who interpreted a NNE-SSW striking fault zone transecting the Mesozoic to Cenozoic strata as recent left-lateral wrench fault in the Peißenberg area, $60 \mathrm{~km}$ south of Munich and close to the Subalpine frontal fault. The fault system in the Upper Jurassic carbonate beds is dominated by $\mathrm{E}-\mathrm{W}$ to NE-SW striking normal faults striking parallel along the Alpine orogenic belt (Figs. 3a, c). Some of these normal faults crosscut mid Tertiary strata while other faults are limited to the Mesozoic strata (Lüschen et al. 2006, Krämer 2009).

Assuming the Andersonian fault-stress concept for normal faulting (Anderson 1951; Fig. 3b), the dominating E-W to ENE-WSW striking normal faults must have been generated in a stress regime with a minimum horizontal stress direction $\mathrm{Sh} \approx \mathrm{N}-\mathrm{S}$. The present-day stress field is however $90^{\circ}$ rotated to this normal faulting stress regime with a present-day minimum horizontal stress direction $\mathrm{Sh} \approx \mathrm{E}-\mathrm{W}$ and a maximum horizontal stress direction $\mathrm{SH} \approx \mathrm{N}-\mathrm{S}$ (Reinecker et al. 2010). This inconsistency between the fault geometry and the recent stress regime indicates the existence of fossil nor- mal faults in a present-day stress regime and may be explained by two major processes: The fossil fault structures might be formed in an extensional stress regime in the late Mesozoic representing a palaeostress field of the passive Neotethys margin (Stampfli \& Borel 2004). Depending on the palaeogeographic reconstruction (e.g. Dercourt et al. 1986, 1993, Frank 1987, Trümpy 1988, Stampfli 1992) of the Neotethys a mid-ocean ridge parallel normal fault generation, a nearly perpendicular transform fault generation induced by rifting and drifting and/or local transpressive pull-apart basin geometries are possible scenarios causing a structural segmentation of the European shelf. Another reason for brittle normal fault occurrences might be related with the Tertiary syn-Molasse subsidence caused by lithospheric bending and local stretching due to tectonic loading of the Alpine fold and thrust belt on the European Plate (Karner \& Watts 1983). Such tectonic load driven flexural bending accompanied by normal faulting in the collisional foredeep of an orogen is observed in other orogenic foreland basins as well (e.g. Bradley \& Kidd 1991, Bry et al. 2004 and references therein) and known from the Alpine Molasse Basin (Matter et al. 1980, Pfiffner 1986, Hsü \& Briegel 1991, Schmid et al. 2004, Kuhlemann \& Kempf 2002).
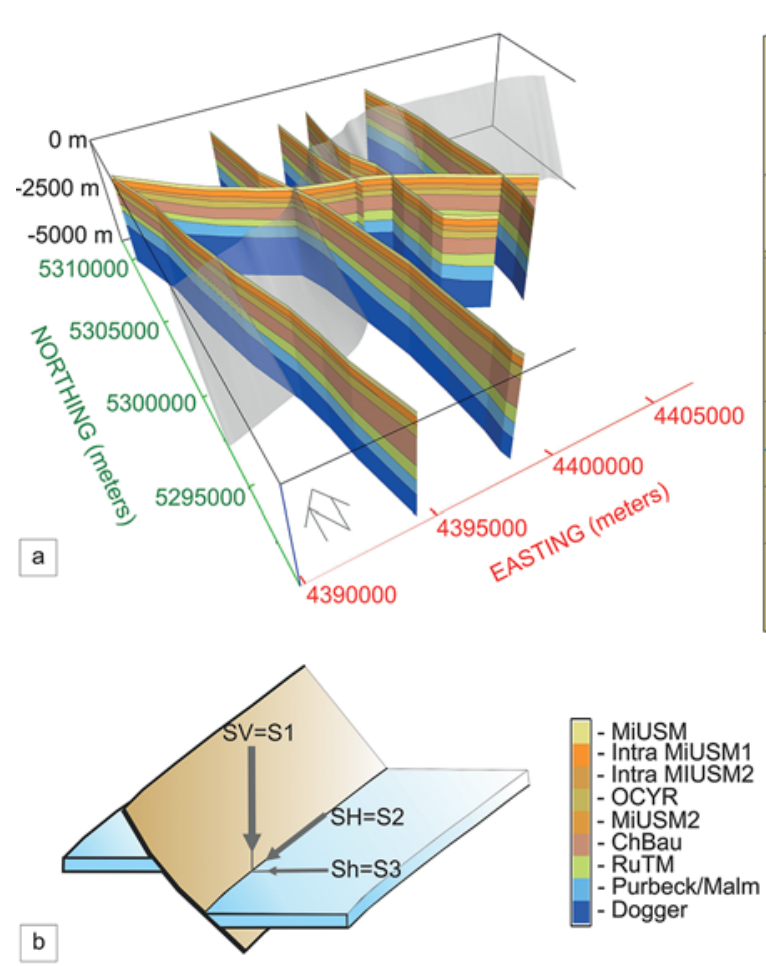
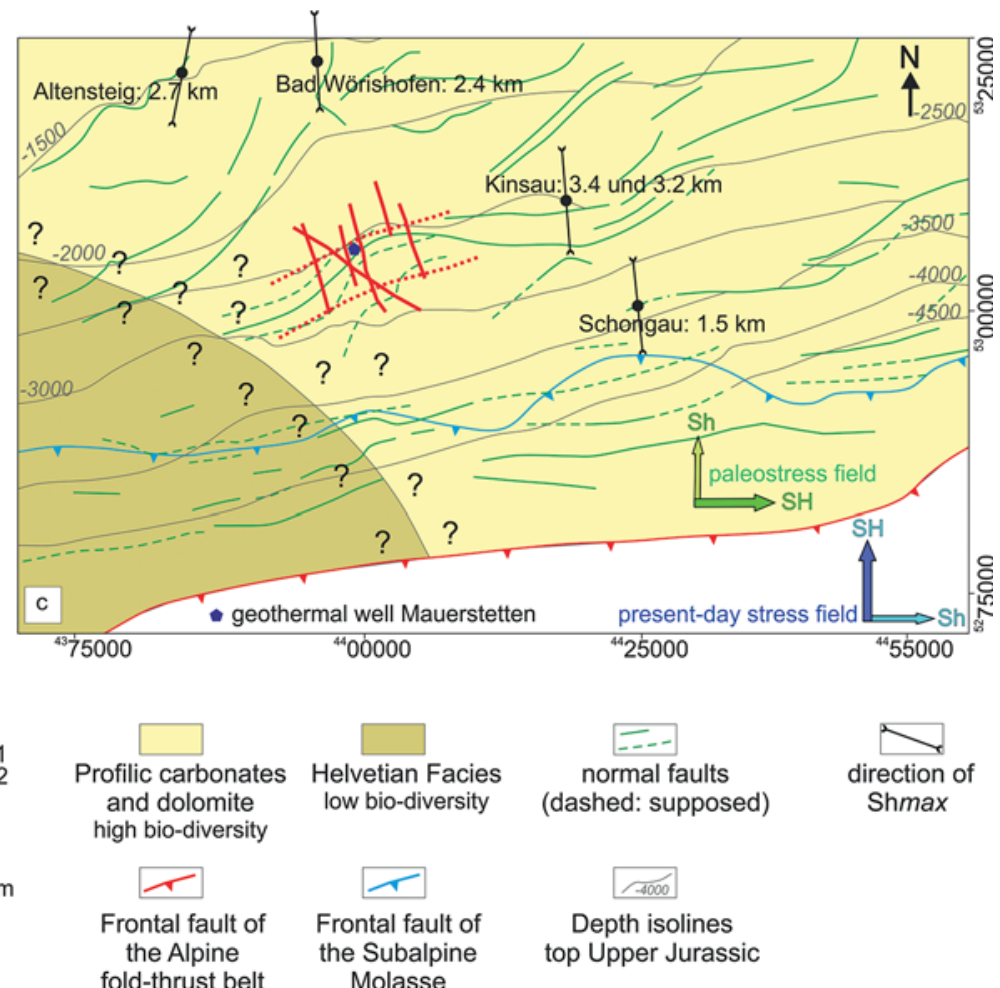

Fig. 3: Location of the geothermal prospect Mauerstetten. (a) 2D seismic profiles, reflexion markers and interpreted normal fault (grey shaded). See Fig. 2 for stratigraphic relation of reflexion seismic markers. (b) Andersonian stress field/faulting regime relation for normal faults. (c) Map of the Upper Jurassic (Malm) carbonate formation. Black polygon: well GT1; red solid lines: 2D seismic profiles used in this study; dashed red lines: 2D seismic profiles used for 3D geological modelling but not used for the stratigraphy related fault throw analysis; question marks indicate the transition region from prolific carbonate facies to Helvetic facies; black dots: neighbouring wells with depth range of borehole breakouts indicating the direction of SH from the present day stress field; green Sh-SH arrows: palaeostress field causing the normal faults; blue Sh-SH arrows: present day stress field causing the Alpine frontal fault (modified from Reinecker et al. 2010, Bayerischer Geothermie-Atlas 2010). 

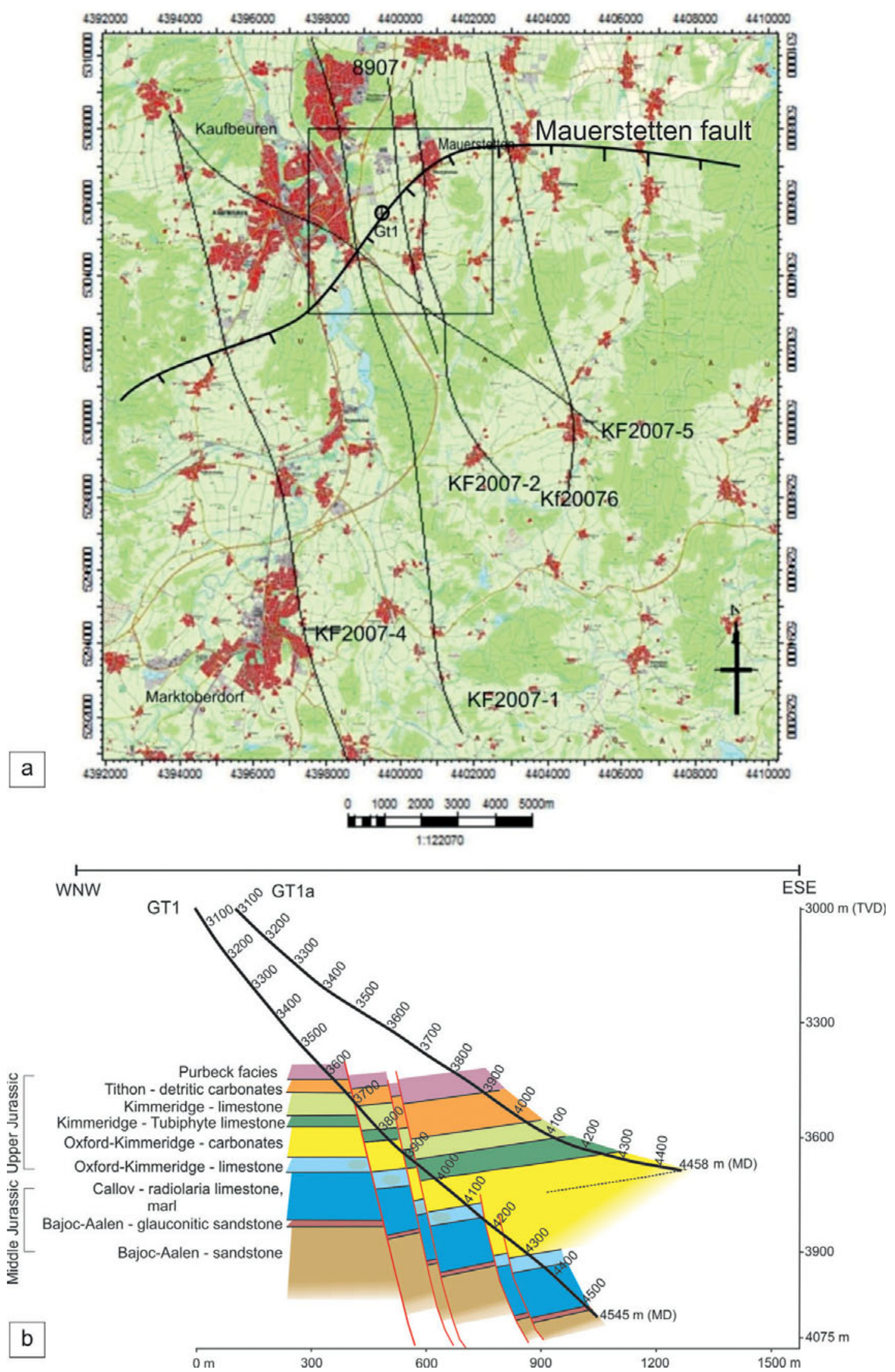

Fig. 4: Overview about seismic line and well locations. (a) Basemap of 2D seismic sections around the well Mauerstetten GT1. (b) Well path of GT1 and GT1a crossing a fault zone interpreted directly after drilling. 
The involved faulting processes may be identified by a quantitative fault zone analysis in seismic sections measuring specifically the fault throw on individual seismo-stratigraphic horizon cut-offs on seismic profiles. The six 2D seismic sections (Fig. 4) of the Mauerstetten prospect cover a major ENE-WSW trending discontinued offset of normal fault array with an absolute throw of $270 \pm 10 \mathrm{~m}$ and a length of $20 \mathrm{~km}$ (Fig. 3a). The fault zone truncates the Upper Jurassic to Miocene strata. However, the fault throw seems larger in the Mesozoic strata than in the Cenozoic strata and declines towards the Miocene in the upper section. A stratigraphy related fault throw analysis is therefore chosen to identify intra-formational fault throws to detect a fault activity at a certain time slot.

\section{Fault throw analysis}

The relevance of a quantitative fault throw analysis is not only of geodynamic interest referring to the evolution of the Bavarian Molasse Basin but also of practical interest for geothermal exploration. Carbonate formations are known as complex dual porosity-permeability fracture-controlled reservoirs where faults and fractures are the main conduits channelling fluids to the production point (Correia et al. 2011). However, faults can either act as conduits or as barriers, and it is the key challenge in exploration to identify these fault characteristics before drilling. One criterion for identifying permeable fault zones before drilling is to analyse their strike and dip as well as their orientation in the current stress field. Critically stressed faults with high shear stresses (Barton et al. 1995, Moeck et al. 2009a, b, Jolie et al. 2012) or extensional faults with low normal stresses acting perpendicular on the fault planar (Gudmundson et al. 2002, Ferrill \& Morris 2003, Ferrill et al. 2009) are considered as prime conduits able to channel high volumes of fluids. In the Bavarian Molasse Basin, this spatial relation between stress field and permeable fault zone does not seem to work as postulated by Barton et al. (1995) or Gudmundson et al. (2002): In the present-day stress field with a direction of $\mathrm{SH}$ in $\mathrm{N}-\mathrm{S}$, extensional faults are striking $\mathrm{N}-\mathrm{S}$ while critically stressed faults are oriented as conjugate shear fracture or strike-slip system consisting of NW-SE and NE-SE faults. The best permeability should be found in these structural patterns. Contrasting, results from current geothermal production tests and regional hydrogeological reservoir simulations show that the approximately $\mathrm{E}-\mathrm{W}$ oriented fossil normal faults act as major conduits and flow zones. Thus, E-W striking faults are considered as prime targets for geothermal drilling projects (Birner et al. 2011, Bartels et al. 2012). These E-W trending fossil normal faults should be experiencing high normal stresses on their planar face in the recent stress regime and should be compressively locked for fluid flow. The E-W faults are perpendicularly oriented to the maximum horizontal present-day stress field caused by the propagating Alpine front with a preferential top north movement (Fig. 3c); therefore the fault plane should be sealed. One reason for the obvious ability of these E-W trending fossil normal faults to act as main fluid conduits although they experience high normal stresses might be explained by the formation of a fault damage zone that skirts a fault as a zone of increased fracture density (Agosta et al. 2007).

The geothermal prospect Mauerstetten portrays a prime study site in the Bavarian Molasse Basin to address these inconsistencies between fault strike (geographic and structural location), stress field determination and permeability structure. The fault kinematic evolution of fossil normal faults will be investigated in a 2D reflection seismic study at Mauerstetten and subsequently compared with hydraulic test data from the deep well accessing the Upper and Middle Jurassic. The borehole consists of one well section that is drilled into the damage zone of a fossil normal fault while a side track is drilled into the undeformed host rock about $650 \mathrm{~m}$ south of the fault zone. During prospection neither of the wells provided economically viable flow rates and the borehole is currently abandoned.

\section{The well Mauerstetten}

The well Mauerstetten GT1 intercepts the fault zone of the afore-mentioned undulating E-W striking normal fault array at a depth of 3,763 m TVD (true vertical depth, i.e. below ground level) encountering the Upper Jurassic aquifer (Figs. 3 and 4). The well is deviated along ESE direction (120 azimuth), inclined at an angle of $50^{\circ}$ and has a total length of $4,523 \mathrm{~m} \mathrm{MD}(4,085 \mathrm{~m}$ TVD). The well path is placed into the hanging wall block of the fault zone and truncates three branches of synthetic normal faults evidenced by calcite filled fractures and geophysical borehole data within the lithostratigraphic section of well GT1 (Fig. 4b). The side track GT1a is placed into the hanging wall of the second fault branch and is drilled in fault dip direction along ESEWNW (108 azimuth) with an inclination of $57^{\circ}$ to $4,052 \mathrm{~m}$ $\operatorname{MD}(3,572 \mathrm{~m}$ TVD) depth with a lateral distance of $513 \mathrm{~m}$ to GT1 in $289^{\circ}$ azimuth. According to a first interpretation the wells are drilled into an en-echelon normal fault zone to explain the repeating intersected lithology found in drill cuttings (Fig. 4b). A detailed facies analysis was not conducted at that point of time. The temperature in $3,675 \mathrm{~m}$ depth TVD measured directly after drilling is around $130{ }^{\circ} \mathrm{C}$ shortly after reaching the target horizon in the main well GT1.

The drilled normal fault zone is visible in the 2D seismic sections as one fault zone, possibly with the synthetic parasitic fault branches. The seismic sections originate from 2007 and were adjoined to older seismic sections from 1989, 1990 and 2003 (Fig. 4a). A total of 12 seismic sections were processed or reprocessed and interpreted to build a 3D geological model (Loske \& Witte 2008). The processing of the seismic data obtained images of good quality of the Upper Jurassic in more than $4 \mathrm{~km}$ depth. The reflection quality of the field traces was good to excellent and surpassed the resolution of previous surveys in the region. The processing results are more coherent with the known stratigraphy and horizons below the top of the Mesozoic are reliably visualised. A good match in terms of static shift and time and phase de- 
viation was obtained with the existing seismic lines from reprocessed neighbouring prospects. After imaging a dominant wavelength was obtained of about $80 \mathrm{~m}$ in a depth of $600 \mathrm{~m}$ and about $130 \mathrm{~m}$ at a depth of $3,000 \mathrm{~m}$. Vertical resolution is usually given as $1 / 4$ of the dominant wavelength. The seismic reference elevation for the project is $650 \mathrm{~m}$ above sea level with replacement velocity of $3,000 \mathrm{~m} / \mathrm{s}$.

The 3D geological interpretation of the seismic sections was achieved with the software PETREL (Schlumberger Information Solutions). Twelve reflection seismic markers could be identified from base of Mesozoic to top Aquitanian at the boundary Lower to Upper Miocene (Figs. 2, 3 and 5). Seven of these 12 seismic horizons can be correlated reliably over the whole interpretation area and are used for the stratigraphy-related fault throw analysis. Strike and dip of the major normal fault is mapped using six of the 12 2D seismic sections. These six seismic sections cross the fault at a high steep angle (Fig. 3). The fault throw measurements are performed in the $3 \mathrm{D}$ geological model along rectangular intersections of faults at the positions of the $2 \mathrm{D}$ seismic sections.
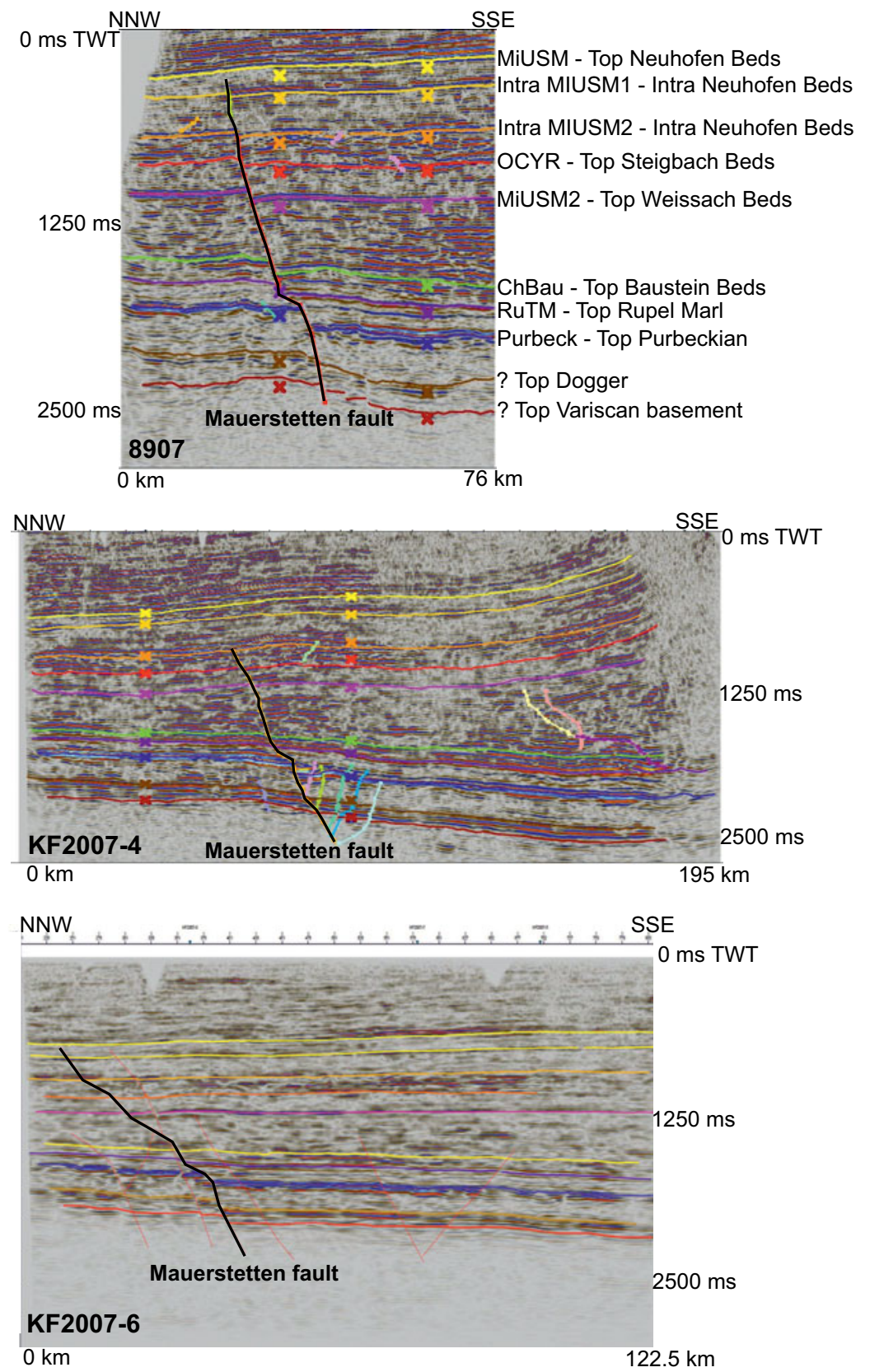

Fig. 5: Three examples of the six 2D seismic sections (top image: section 8907, centre image: section KF2007-4, base image: KF2007-6) used for the fault throw analysis of the Mauerstetten fault. For stratigraphy and seismic reflexion markers, see Fig. 2 . TWT $=$ two way travel time; $\mathrm{ms}=$ milliseconds; coloured crosses are signatures for seismic reflector picking. 
These adjusted areas show the least uncertainty in the 3D geological model because they correspond to transects of input data and thus are least affected by interpolation effects from the gridding process during model building.

After concluding the model fit, two methods were used to determine the growth history of the studied fault zone: (i) the fault throw was measured sequentially through all mapped seismic horizons from the uppermost faulted layer with an identifiable cut-off in the lower marine Molasse (i.e. the lower Neuhofen Beds; Fig. 5) down to the Purbeckian that represents the topping of the Upper Jurassic carbonate reservoir. The throw measured on each seismic horizon was subtracted from the throw of the next lower horizon in order to detect the differential offset for each layer instead of only measuring the cumulative offset. The differential offset is referred as to "Quantitative Fault Expansion Index" (QFEI) and is given in metres (Fig. 5); (ii) the thickness variation of seismic stratigraphic intervals was measured in the footwall and hanging wall adjacent to the fault plane. The thickness of the seismic horizon in the hanging wall was compared with the thickness of the same layer in the footwall at the intersection of the horizons with the fault plane. The thickness variation from hanging wall to footwall is expressed in percent and referred as to Expansion Index. In the case that the horizons have the same thickness in hanging and footwall, the Expansion Index is 1. Has the hanging wall horizon a $10 \%$ higher thickness than in the footwall, the expansion index is added by $10 \%$ resulting in 1.1 , with a $20 \%$ higher thickness from hanging to footwall layer the expansion index is 1.2. The thickness is measured vertically to the horizon base, respectively, so that an apparent thickness in rotated fault blocks can be excluded. This second method aims to discriminate synsedimentary growth faulting from postsedimentary faulting while the first method aims to identify the fault activity at a certain period. A similar approach was applied by Tvedt et al. (2013) for analysing normal fault growth in multi-layered sequences in the Egersund Basin in the Norwegian North Sea, and by Budach et al. (2017) for a fault system in the Upper Jurassic at the geothermal prospect Unterhaching in the Bavarian Molasse Basin.

\section{Results}

The stratigraphy-related fault throw analysis shows different magnitudes of the Quantitative Fault Expansion Index (QFEI), i.e. faulting activity at a certain time period. The results are presented along the Mauerstetten fault from east to west in the order of seismic sections KF2007-4, KF2007-1, KF2007-5, 8907, KF2007-2, KF2007-6 (Figs. 4, 6a-f).

The seismic section KF2007-4 transects an ENE-WSW striking segment of the normal fault. This fault experienced a minor QFEI in the Lower Miocene (Aquitanian) and Upper Oligocene (Chattian), larger QFEI in the early Upper Oligocene and the largest QFEI in the Lower Oligocene (Rupelian). The QFEI of the Purbeckian indicates the active phase of this fault segment in the Late Mesozoic (after the deposition of the Purbeck) and before the Rupelian period in the
Lower Oligocene (Fig. 6a). The cumulative fault throw is $250 \mathrm{~m}$. The thickness of the formations between the top Baustein Beds to the top Weissach Beds increases to the south. In the older stratigraphic units the dip is gently to the southeast and in the hanging formation top to the northwest. Between kms 145 to 160 (yellow and pink line depicting secondary normal faults; Fig. 5) also reverse faults and flatramp structures may be localised.

The seismic section KF2007-1 transects the normal fault at a NE-SW striking segment. The youngest fault activity occurred with a minor QFEI in the Aquitanian with a culmination of faulting activity in the Upper Oligocene and still major fault activity from Upper to Lower Oligocene and Mesozoic. This NE-SW striking fault segment was clearly formed during the Mesozoic indicated by a QFEI of $38 \mathrm{~m}$ (Fig. 6b). The cumulative fault throw is $238 \mathrm{~m}$.

The seismic section KF2007-5 transects the normal fault also at a NE-SW striking segment. At this segment of the Mauerstetten fault latest faulting activity occurred in the Lower Burdigalian and continued with a culmination of faulting activity at the boundary Upper to Lower Oligocene. The QFEI in the Purbeckian indicates a fault formation in the late Mesozoic or lowermost Tertiary (Fig. 6c). The cumulative fault throw is $192 \mathrm{~m}$.

The seismic section 8907 transects the normal fault as well at a NE-SW striking segment and shows the largest QFEI in the Burdigalian (Fig. 6d). This fault segment was continuously active from Upper to Lower Oligocene and was formed as the other fault segments from the Early Mesozoic to the earliest Neogene (Fig. 5). The cumulative fault throw is $232 \mathrm{~m}$.

The seismic section KF2007-2 transects the normal fault at a curved segment striking NE to ENE. A small QFEI in the Burdigalian is followed by a larger QFEI in the Aquitanian and a culmination of faulting activity at the boundary Upper to Lower Oligocene. A minor offset of the Purbeckian indicates an initial formation of this fault segment in the later Mesozoic or early Cenozoic (Fig. 6e). The cumulative fault throw is $266 \mathrm{~m}$.

The seismic section KF2007-6 transects the normal fault at an E-W striking segment. This fault segment was not active in the Miocene and experienced its latest faulting activity in the middle Upper Oligocene (Fig. 5). The major faulting activity occurred in the Lower Oligocene and started with another major QFEI in the late Mesozoic or earliest Cenozoic before deposition of the Rupelian sediments (Fig. 6f). The cumulative fault throw of this fault segment is $236 \mathrm{~m}$.

The Expansion Index illustrates the synsedimentary activity of these segments of the Mauerstetten fault (Fig. 7). Highest synsedimentary normal faulting activity was in the Lower Oligocene along all fault segments with up to $40 \%$ thicker hanging wall beds than footwall beds of the Rupelian sediments. Synsedimentary activity occurred also especially along the NE-SW striking fault segments during Upper Oligocene and Middle Miocene (Burdigalian). 

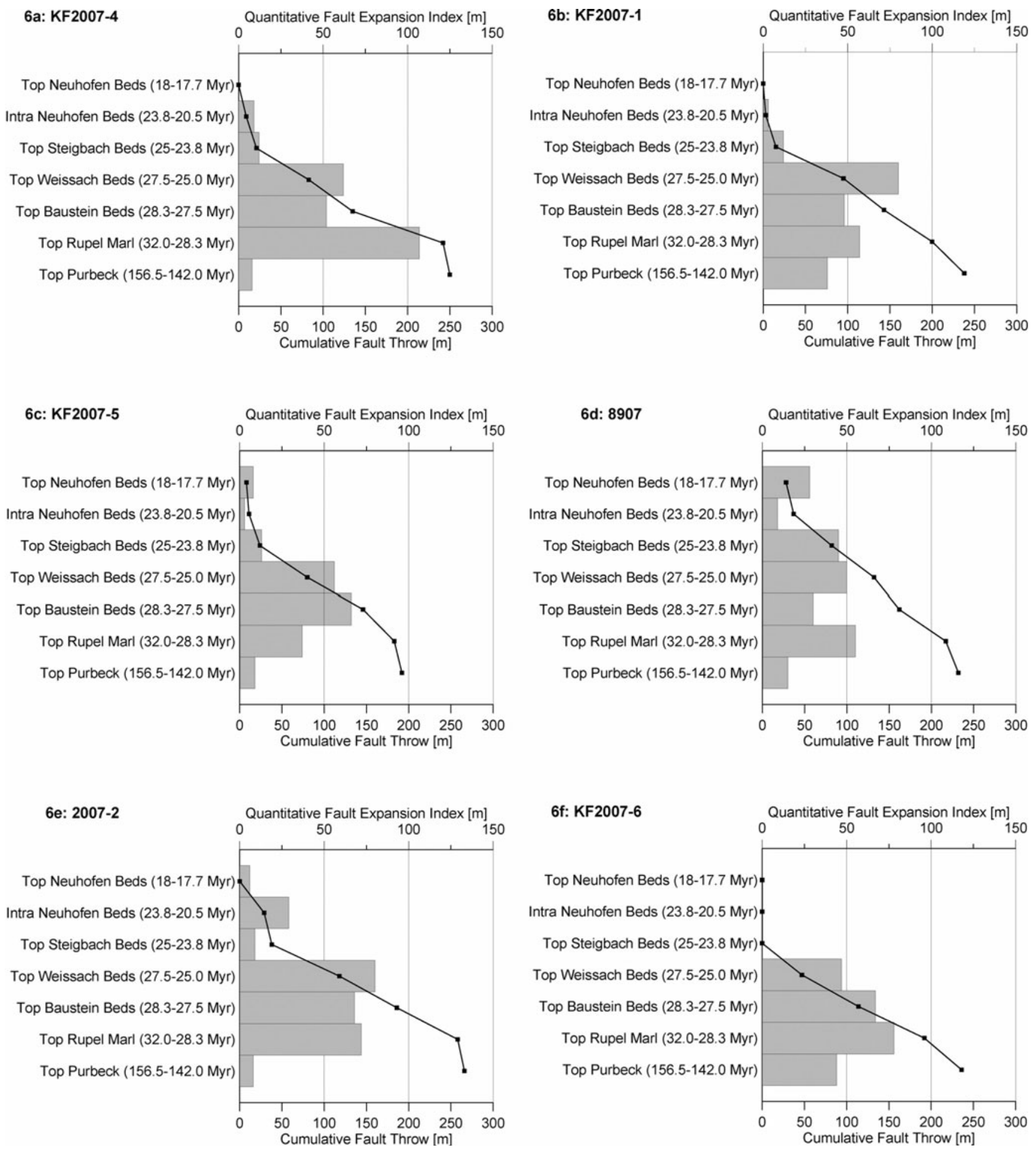

Fig. 6: (a)-(f) Results of fault throw analysis on the six 2D seismic sections crossing the Mauerstetten normal fault zone. Grey bars $=$ quantitative fault expansion index (QFEI), illustrating the fault throw per time unit; black line = cumulative fault throw. The zero point of the cumulative fault throw is related to the uppermost grey bar, illustrating the youngest detectable fault throw. 


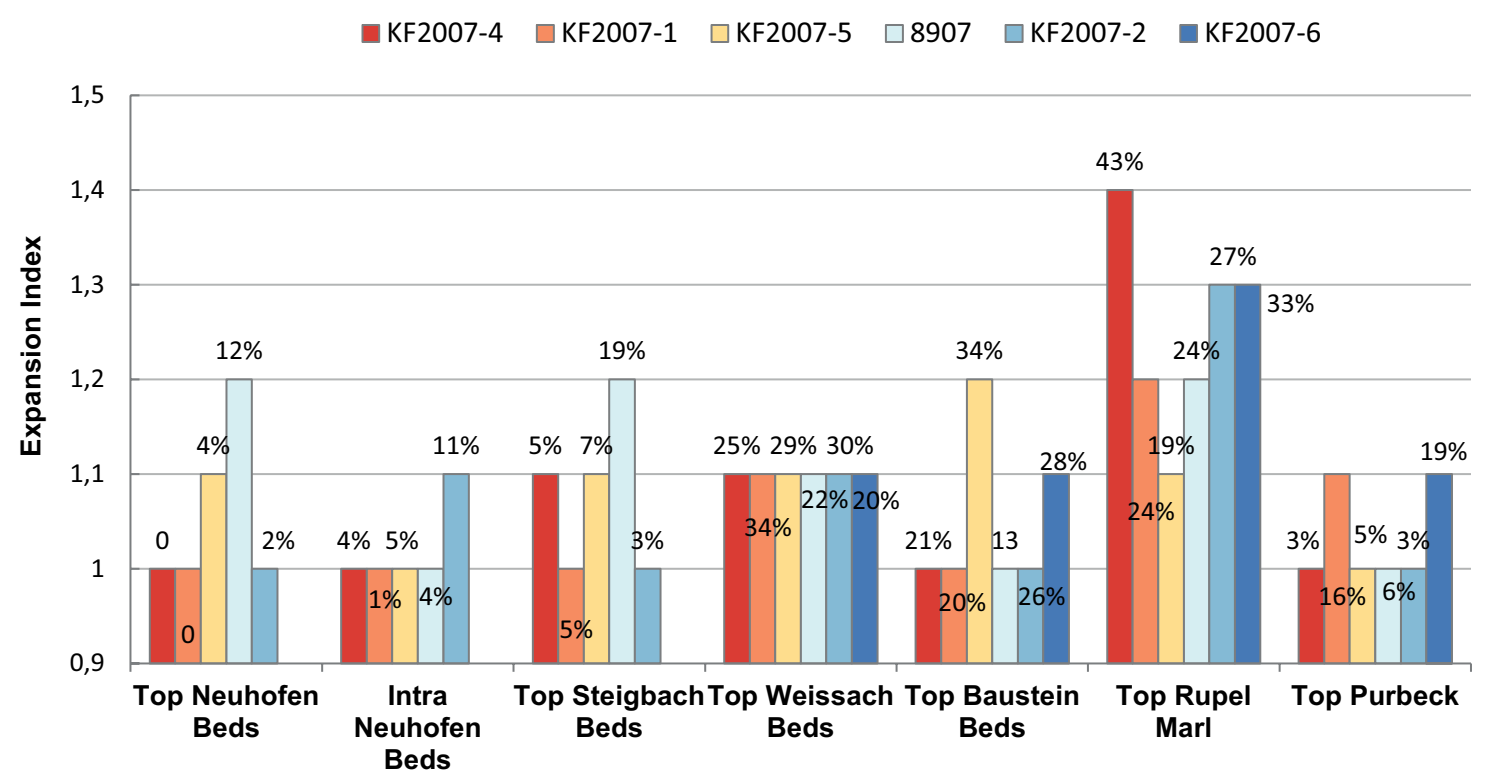

Fig. 7: Expansion index of the Mauerstetten fault, indicating synsedimentary growth faults if the expansion index is above 1.1 (more than $10 \%$ thickness increase in the hanging wall towards the footwall of the fault).

\section{Fossil faulting phases and current fault stress state}

The QFEI derived from the fault throw analysis indicates the inactivity of the fault since the Middle Miocene (17 Ma) confirmed by the absence of natural seismicity in the present-day stress field at Mauerstetten (Barnikel \& Geiss 2008). The present-day stress state of the faults and their likelihood for fault slip can be estimated by the slip tendency and derived fault reactivation potential (Morris et al. 1996, Moeck et al. 2009a) following the concept of limiting stress ratios and the Mohr-Coulomb failure criterion extended by the Hoek-Brown parameters (Moeck et al. 2009b, Cacace et al. 2013). Two important facts can be addressed: (i) the orientation of fault segments with high slip ratio; (ii) the conditions for slip depending on rock strength and fluid pressure. Assuming a present-day strike-slip stress regime in the Mesozoic succession (Cacace et al. 2013, Reinecker et al. 2010) with a maximum horizontal stress direction $\mathrm{SH} \approx 170^{\circ}$ $\left( \pm 15^{\circ}\right)$ (Moeck \& Backers 2011), an estimated fair rock mass quality with fracture spacing at $0.3-1 \mathrm{~m}$ (Moeck et al. 2009a) accounting for the fractured fault damage zone as indicated by the lithology of the well GT1, and hydrostatic conditions of $35 \mathrm{MPa}$ for the Upper Jurassic reservoir in Mauerstetten, the slip tendency on any segment of the normal fault is below the friction coefficient of the rock mass. This result is another indicator for a fossil normal fault with no probability of reactivation in the current stress field. $\mathrm{E}-\mathrm{W}$ trending fault segments with dip angles $>42^{\circ}$ cannot be reactivated as reverse faults in the current stress field. With a dip angle $<42^{\circ}$ these faults could be reactivated as reverse faults. NNE and NNW trending faults could be reactivated as sinistral and dextral strike slip faults, respectively.
The observed normal fault with an E-W to NE-SW trend in the Mauerstetten area has significantly steeper dips $\left(>45^{\circ}\right)$. Thus, these fault segments undergo frictional blocking and are unlikely to be reactivated. Therefore, unusually high horizontal stresses would be necessary to reactivate these faults as reverse faults. Obviously this is not the case because no indication for reverse faulting reactivation (such as anticlinal bending of the hanging wall formations) is observed in the 3D geological model. An additional fluid pressure of $33 \mathrm{MPa}$ would be required to reactivate NE-SW segments of the normal fault in fairly fractured rock indicating an inactive normal fault exhibiting fossil multiphase activity.

The progressive step fault structure in seismic section 8907 is sealed by the Middle Jurassic (Dogger) horizon. In the well site region an anticlinal flexural deformation is evident for the horizons between the top basement and the top Middle Jurassic, indicating compression, transpression or inversion. No differences in thickness are found in the footwall and hanging wall of this fault segment evidencing a low tectonic activity during sedimentation. At Mauerstetten, extension prevailed in Jurassic time because to the southeast of the fault a synclinal structure is found between the top Middle to top Purbeck (section 8907). Next, an important offset is found in sections 8907 and KF2007-6 where the fault transects the top Purbeck horizon. In section KF 2007-4 a complex graben structure with a first order normal fault dipping to SSE and a secondary conjugate normal fault dipping to the NNW is evident below the Rupel Clay horizon. Several parasitic antithetic faults are found between them. This is a typical extensional fault pattern of a half-graben. In section KF2007-6 some synthetic and antithetic faults are found below the Rupel Marl, but an evolved half-graben structure is not detected. Faults are discontinuously and stratiformly 
sealed by post-extensional horizontally layered sediment formations of an age older than Rupelian.

Trying to interpret in more in detail the pre-Rupelian structure at the fault in section KF2007-4, one might see a possible anticlinal bending between both graben normal faults. Specifically, between the parasitic yellow and light green fault a bulging structure deforms the top Purbeck (Fig. $5 a)$. In the Rupelian the bedding is back to horizontal bedding. Accepting this interpretation, compression in the Late Cretaceous could have inverted the half-graben into a flower structure with an uplift of the central part and smooth folding in the centre of the structure. This may explain the smaller offset (8907) of the top Baustein Beds (nearly none in KF2007-4) compared to the top Purbeck. Also the change in dip at the Rupel Marl probably compensates part of the dislocation. Another reason for this antiformal structure could be an algal build-up indicating a depositional rather than a structural origin.

Section 8907 is close to the well site and there the halfgraben structure is not developed. This can be explained with the fault plane in this segment striking SW-NE. The fault strike is perpendicular to Late Cretaceous W to NW compression in the Austroalpine and Penninic tectonic units. Also a transpressive sinistral shear was induced on the European shelf (Dercourt et al. 1986). Thus, faults facing to the west and southwest are much stronger affected by transpressional shear than $\mathrm{E}-\mathrm{W}$ segments of the same fault where the extensional structures are preserved.

In the Chattian the QFEI is still large. This time corresponds to the main deformation in the Subalpine Molasse and the beginning of thrusting onto the Plateau Molasse (Schmid et al. 1996). The E-W faults are interesting targets for prospecting, because at different times from the Permian to the Miocene a normal fault could be reactivated and at the Alpine front an important hydrothermal flow is known from the wells Hindelang and Au, documented by Müller (1985), Kuckelkorn \& Hiltmann (1985), Colins De Tarsienne et al. (1987). The exploration focus for production wells should probably be concentrated on normal faults activated first in the postVariscan time and being active until the Alpine thrusting and associated foreland basin formation during the Tertiary.

\section{Carbonate facies analysis on drill cuttings}

In addition to fault and stress analysis, the geology and geological setting of both wells was determined as well as the fault pattern of the Upper Jurassic reservoir on a smaller scale than the seismic surveys. At the geothermal site Mauerstetten the geology of the drilled carbonate rocks, analysed by drill cuttings of GT1 and GT1a, added to geophysical log data interpretation of GT1. The carbonate rocks were described with regard to their petrography and microfacies according to Folk (1959) and Dunham (1962), mineralisation (dedolomitisation, calcification, silification), as well as the primary and secondary porosity. In a further step, the layers encountered in both wells were compared with facies description of the
Franconian, Swabian and Helvetic facies (Meyer \& SchmidtKaler 1989, Schneider 1962). Additionally, the intersected lithological layers between both wells (GT1 and GT1a) were compared and correlated. Absolute age determinations of the Upper Jurassic carbonates were not conducted.

For the evaluation of the carbonate facies about 500 thin sections of drill cuttings were used, which have been taken within a sample interval of $5 \mathrm{~m}$ drilled depth in the Upper Jurassic. Hence, the thin sections show a mixture of different lithologies which are intersected in the open-hole section at one time and do not contain clayey rocks, as the clay material is usually disintegrated by the drill mud. The cutting thin sections were in addition half-sided stained by an Alizarin Red S solution to dye calcite crystals. The examination of the thin sections was conducted with a standard transmission polarised light microscope. The classification of the carbonates was done according to Folk (1959) and Dunham (1962), the coated grains and skeletal grains (bioclasts) are described following Flügel (2010), and the organisms were classified by the facies types (Flügel 2010) to determine the depositional setting at Mauerstetten.

\subsection{Description and results of GT1 and GT1a}

The stratigraphic layers of the Upper Jurassic have an intersected thickness of $486 \mathrm{~m}$ TVD in GT1 and a minimum intersected thickness of $143 \mathrm{~m}$ in GT1a at the project site Mauerstetten. The lithological terms "Peloolith" and "Saccocoma Limestone" were given during this investigation and do not belong to the official lithostratigraphic classification. The stratigraphic column of Mauerstetten (Table 1) begins with the brackish to terrigeneous Middle Jurassic (Dogger) strata. They were followed by the pelagic Radiolarian Limestone and the Saccocoma Limestone (early Upper Jurassic). These deposits were covered during a regression by the Peloolith and Tubiphytes Limestone (Fig. 8), shallow marine deposits of the platform. On top of the Tubiphytes Limestone are deposits of the Sponge Spicules Limestone, the Debris Limestone and Peloomicrite. The transition from the uppermost layers of the Upper Jurassic and Purbeck strata to the Cretaceous deposits coincides with a change from platform carbonates to brackish sediments and an erosional discordance, followed by a transgressive cycle of the Cretaceous. Only the peloolith, a peloidal-ooidal grainstone, shows porosity in some cements. The carbonate rocks in GT1 show calcite veins and stylolites (Fig. 8). There was an increase in stylolite densities and recrystallisation of the limestone to the calcite cement filled fractures. The depositional environment of GT1 is diverse and shows recurring lithology and reef building. An indication of possible fractures can be the occurrence of coarse-grained hypidiomorphic to idiomorphic calcite crystals. However, no further assumptions can be made whether the fractures are completely or partly filled by sparitic calcite.

The abundant organisms within the drilled carbonates were classified with the use of facies types (Flügel 2010). The limestones of the Upper Jurassic are composed of differ- 
Table 1: Lithofacies types of the wells GT1 and GT1a. Seven lithofacies were distinguished based on the Dunham and Folk texture, as well as main components.

\begin{tabular}{|c|c|c|c|}
\hline Time & Lithofacies & Description & $\begin{array}{l}\text { Classification according to } \\
\text { Folk (1959) and Dunham (1962) }\end{array}$ \\
\hline \multirow[t]{6}{*}{$\begin{array}{l}\text { Youngest } \\
\text { Upper } \\
\text { Jurassic }\end{array}$} & $\begin{array}{l}\text { Peloomicrite } \\
\text { (only in GT1a) }\end{array}$ & $\begin{array}{l}\text { Peloidal fabric, micritic limestone with rare fossils } \\
\text { (sponge spicules, foraminifera, echinoids, skeletal } \\
\text { grains and benthic foraminifera) }\end{array}$ & Biomicritic packstone \\
\hline & Debris Limestone & $\begin{array}{l}\text { Sparitic grading into a micritic unsorted limestone } \\
\text { with fossils (bryozoans, echinoderms, sponges } \\
\text { (calcareous and siliceous), Tubiphytes, foraminifera, } \\
\text { peloids, and shell fragments of mollusks) }\end{array}$ & $\begin{array}{l}\text { Unsorted and in parts poorly washed } \\
\text { biosparite; packstone to grainstone, in } \\
\text { parts bindstone }\end{array}$ \\
\hline & $\begin{array}{l}\text { Sponge Spicules } \\
\text { Limestone }\end{array}$ & $\begin{array}{l}\text { Micritic limestone with abundant sponge spicules, in } \\
\text { some parts peloids and microbial mats with sparite }\end{array}$ & $\begin{array}{l}\text { Bioclastic, fossiliferous wackestone to a } \\
\text { sparsely packed packstone or grainstone }\end{array}$ \\
\hline & $\begin{array}{l}\text { Tubiphytes } \\
\text { Limestone }\end{array}$ & $\begin{array}{l}\text { Carbonate grains (e.g. ooids), Tubiphytes and } \\
\text { microbial mats }\end{array}$ & $\begin{array}{l}\text { Poorly washed biosparitic floatstone to } \\
\text { rudstone }\end{array}$ \\
\hline & Peloolith & $\begin{array}{l}\text { Ooids, peloids, crinoids, mollusks and foraminifera } \\
\text { within a sparry limestone which can be in parts } \\
\text { grading into a micritic limestone }\end{array}$ & $\begin{array}{l}\text { Peloosparite and in parts a peloomicrite; } \\
\text { peloidal-ooidal grainstone to packstone }\end{array}$ \\
\hline & $\begin{array}{l}\text { Saccocoma } \\
\text { Limestone }\end{array}$ & $\begin{array}{l}\text { Micritic limestone with sponge spicules and } \\
\text { Saccocoma sp. }\end{array}$ & Sparse biomicritic wackestone \\
\hline $\begin{array}{l}\text { Latest Upper } \\
\text { Jurassic }\end{array}$ & $\begin{array}{l}\text { Radiolarian } \\
\text { Limestone }\end{array}$ & Planktonic organisms within a micritic limestone & Fossiliferous wackestone \\
\hline $\begin{array}{l}\text { Middle } \\
\text { Jurassic }\end{array}$ & $\begin{array}{l}\text { Glauconitic } \\
\text { sandstone }\end{array}$ & $\begin{array}{l}\text { Marl to argillaceous limestone, sandstone with } \\
\text { iron-ooids, and pelagic limestone }\end{array}$ & \\
\hline
\end{tabular}
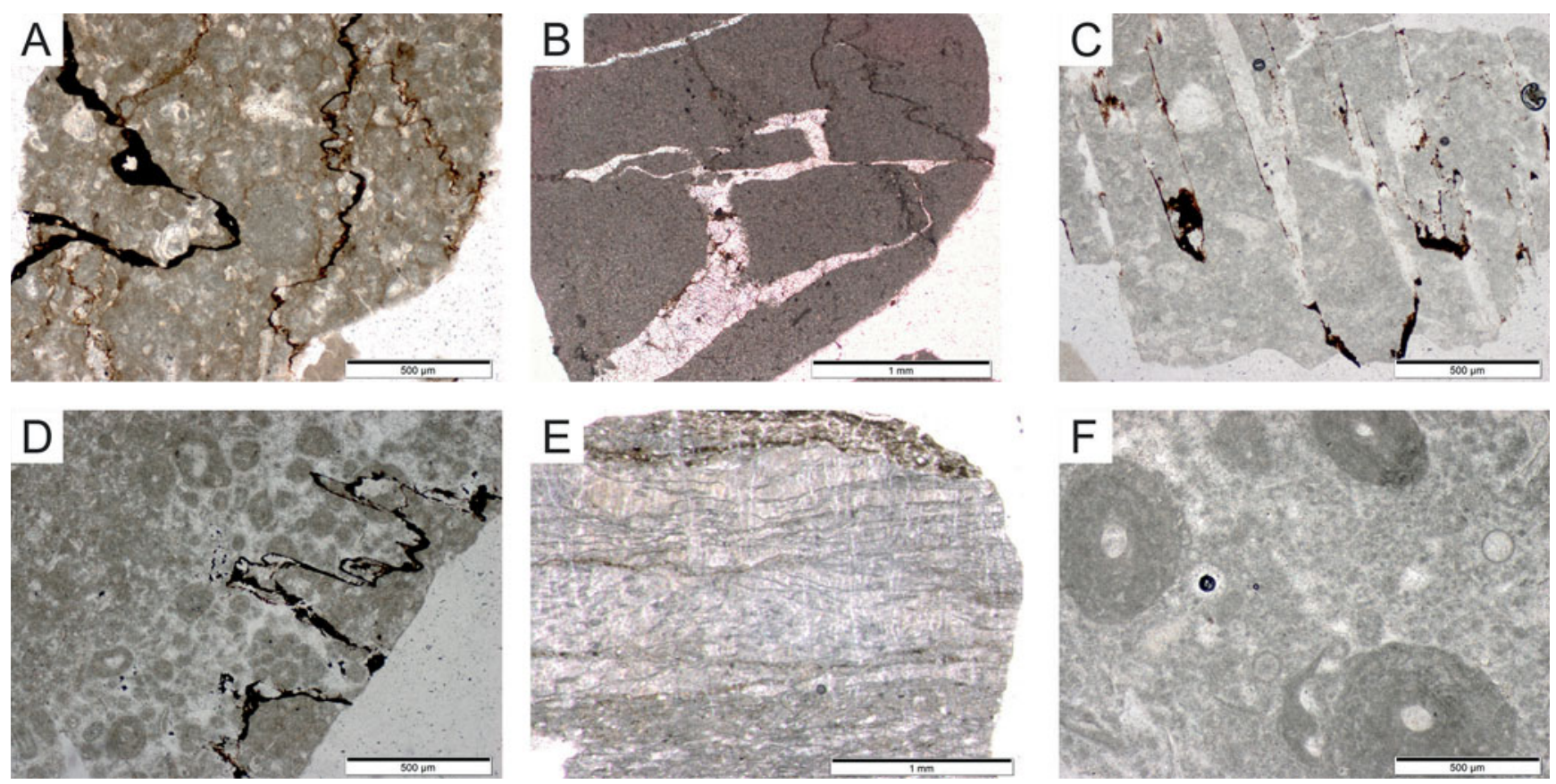

Fig. 8: Thin section photos of the cutting rock samples of the well Mauerstetten GT1 in transmitted light. (A)-(D) Increased pressure solution and stylolites; some stylolites show precipitated calcite crystals. (E) Bindstone with algae crusts. (F) Bioclastic grainstone with Tubiphytes; as all Tubiphytes are cut in the same orientation, an in-situ conservation was assumed. 
ent platform carbonates, which were deposited in a calm water facies. These limestones were additionally calcified, dolomitised, silicified and fractured during diagenesis. Hence, for the processes of dolomitisation, calcification and silification a circulation of $\mathrm{Mg}$-, $\mathrm{Ca}$ - or Si-rich fluids was necessary, which precipitated within the geological strata. Karstification could not be identified or classified. Indicators for karstification could have been clayey material along fractures, changes in the gamma log due to a higher clay content and increase in caliper log. Dolomitised areas are intersected in both boreholes, and have a thickness of around $330 \mathrm{~m}$ TVD (490 m MD) at GT1 and at GT1a around $264 \mathrm{~m}$ TVD (530 $\mathrm{m} \mathrm{MD})$. The dolomite is either a replacive matrix dolomite or developed as a dolostone with a subhedral to anhedral mosaic after Sibley \& Gregg (1987).

\subsection{Facies type of Upper Jurassic in boreholes GT1 and GT1a}

The facies of Mauerstetten is consistent with the Franconian facies, but not with the Helvetic facies. The descriptions of the different regional facies as Franconian facies, Swabian facies and Helvetic facies are according to Koch et al. (1994, 2010), Meyer \& Schmidt-Kaler (1989), Niebuhr \& Pürner (2014), Reinhold (1998), Leinfelder et al. (1993, 2002), Scholz (1995) and Schneider (1962).

The carbonate rocks of GT1 and GT1a cannot be assigned to the typical massive or bedded facies described for the Franconian facies (Niebuhr \& Pürner 2014).The facies at Mauerstetten is characterised in some parts by build-ups of small reef-like microbial crusts and sponge reefs. Therefore, the limestones are consistent with the massive facies, as ooids and smaller reef buildings belong to the reef facies after Meyer (1994). The carbonate rocks of GT1 and GT1a show in the earliest Upper Jurassic deposits of a pelagic influenced environment (Saccocoma Limestone / filament limestone), and are similar to well descriptions in the area around $\mathrm{Mu}-$ nich (Wolfgramm et al. 2012). The typical reef structures of the Frankenalb Fm. at the Franconian Alb (Meyer \& SchmidtKaler 1989) and in deep boreholes around Munich (Wolfgramm et al. 2012), is only slightly developed in Mauerstetten. Reef building is interrupted a few times due to a possible synsedimentary activity of the fault or by a eustatic sea-level change at Mauerstetten. The comparison of the drill cuttings and identified facies from both wells lead to a new interpretation of the Upper Jurassic well sections (Fig. 9). One possibility for the planktonic influenced limestones can be an increased water depth compared to the Franconian facies during the earliest Upper Jurassic. During the Upper Jurassic, the depositional environment of Mauerstetten became shallower due to a possible regression and reef building was then possible. None of the cuttings from the wells GT1 and GT1 a show significant porosity. Therefore, the carbonate rocks at the Mauerstetten site have a low matrix porosity and represent a low permeable tight rock mass.

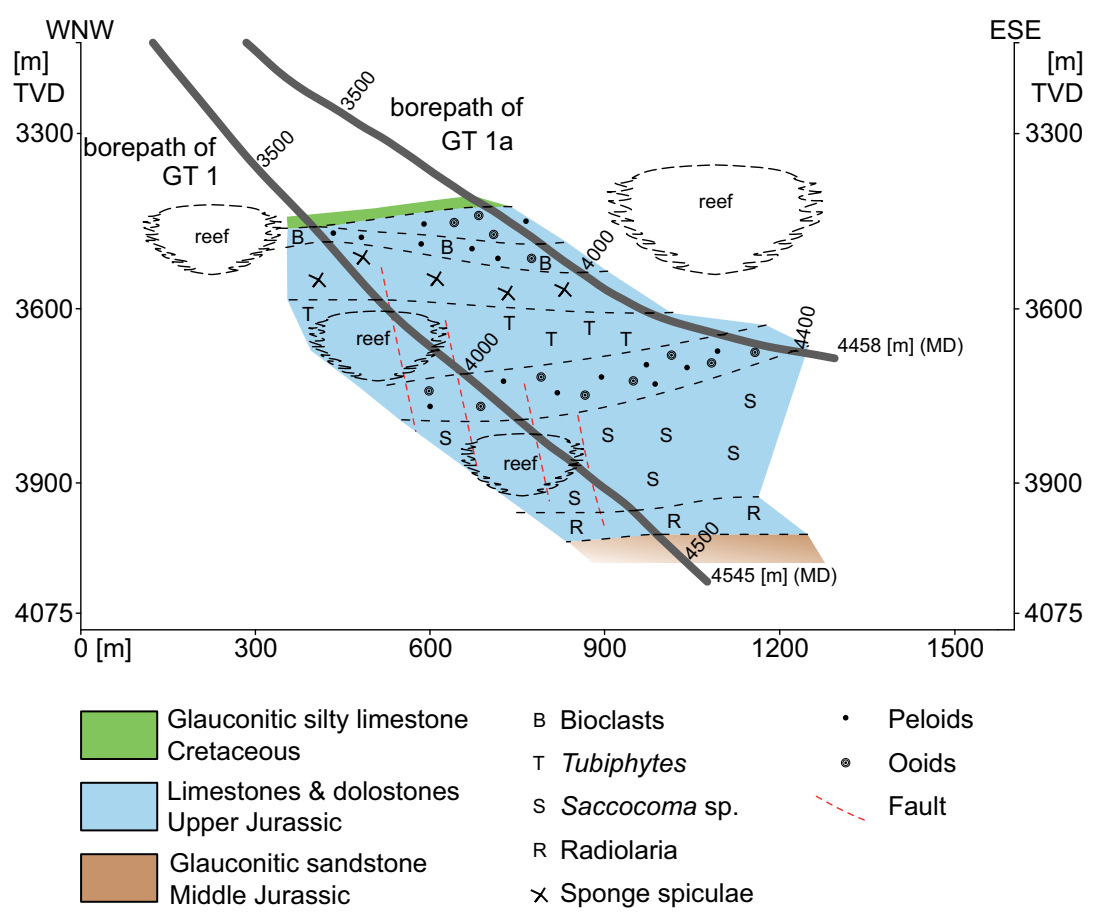

Fig. 9: Geologic section of the well Mauerstetten GT1 and crossed parasitic faults interpreted from drill cutting lithology and geophysical borehole measurements. Parasitic faults are not detectable in 2D seismic. MD = measured depth; TVD = true vertical depth; stratigraphy see Fig. 2. 


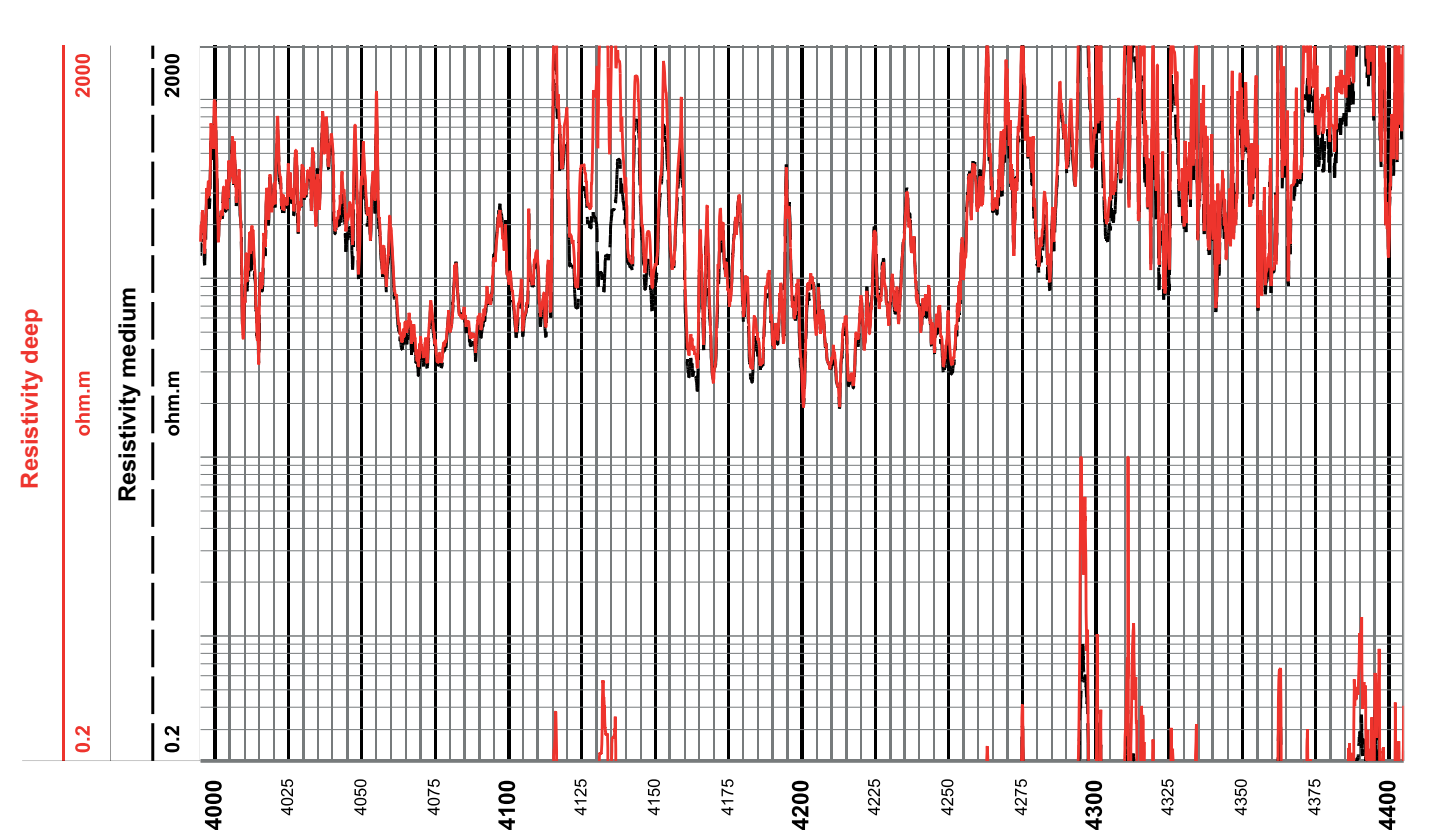

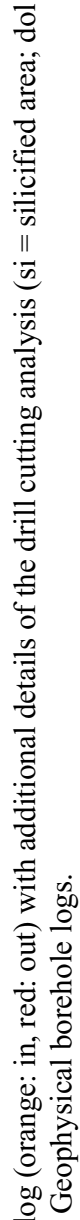
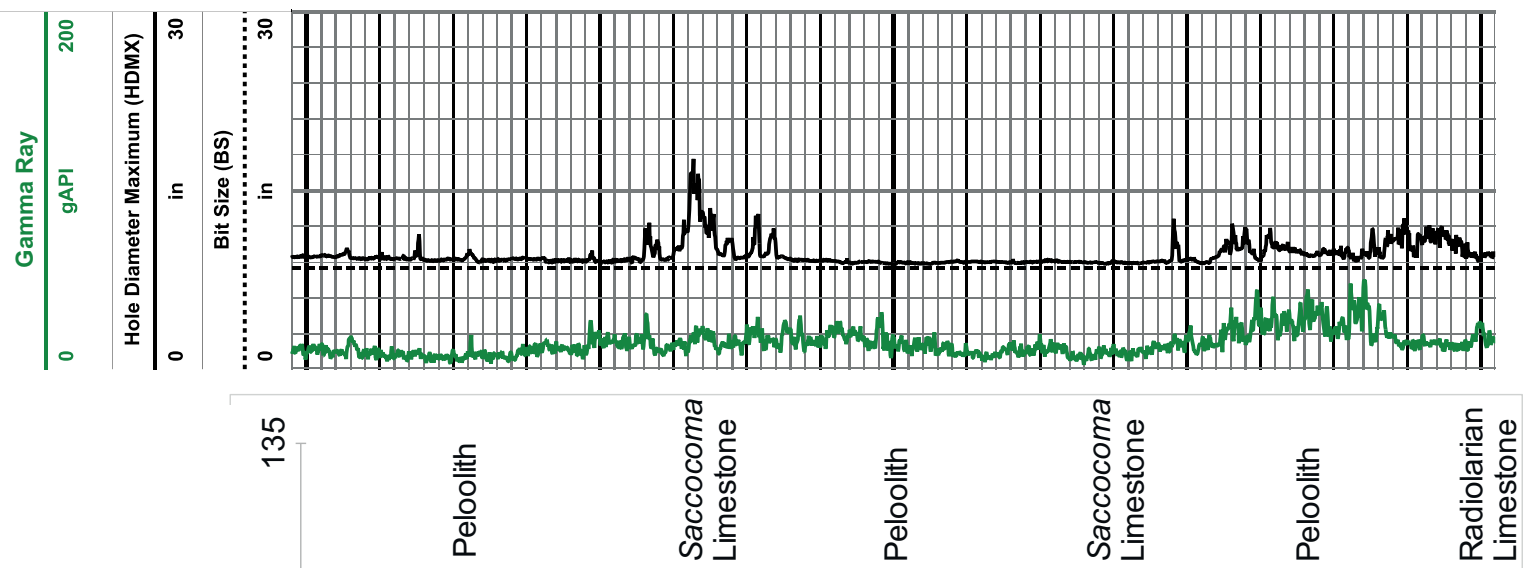

冚

풍

楁 $\frac{0}{2}$

苛

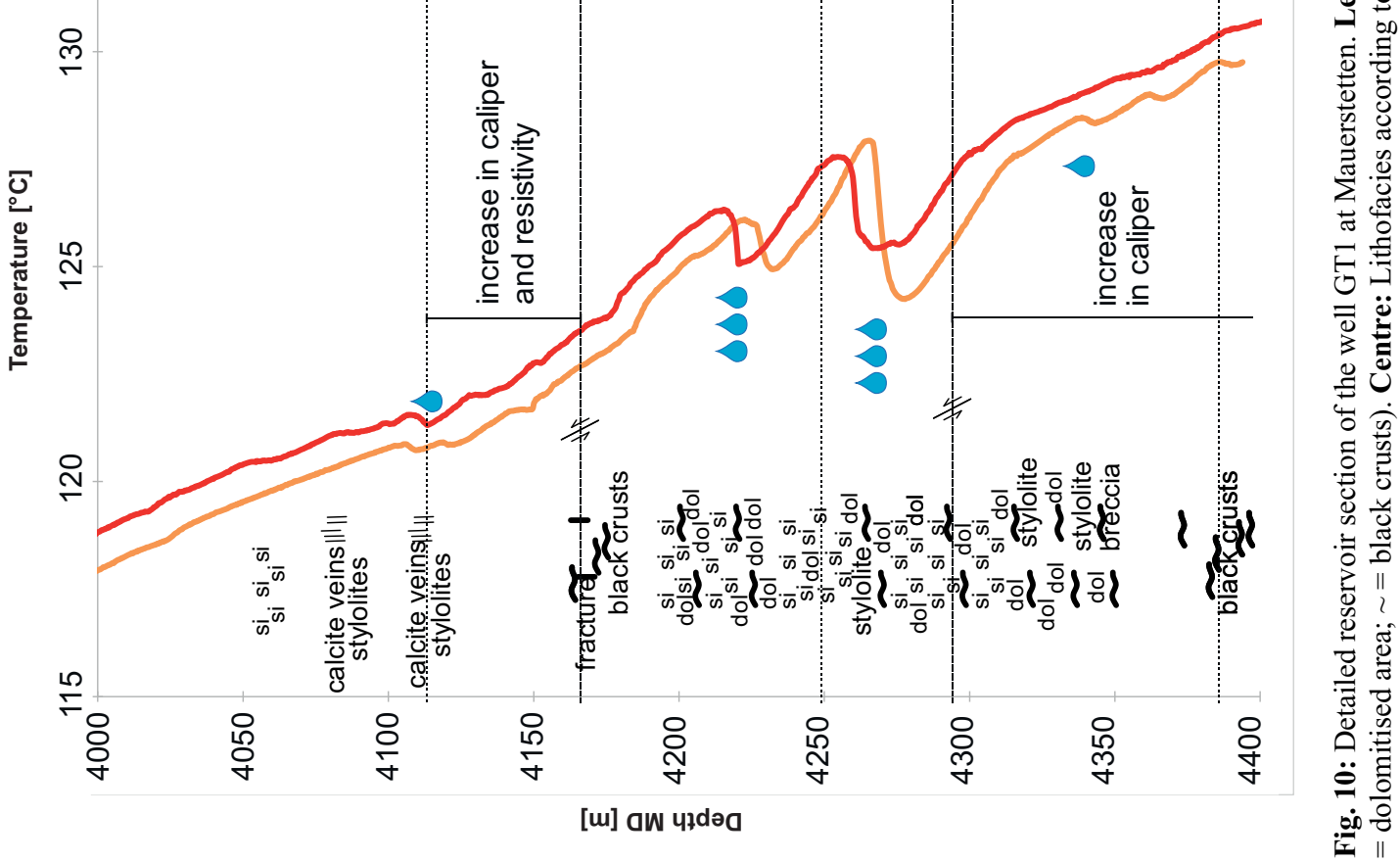




\subsection{Comparison of GT1 and GT1a to geophysical data}

The geophysical borehole data of GT1 show a good correlation between the natural gamma ray, sonic velocity, caliper and electrical resistivity with the lithology described from cuttings. Using this correlation, the depth of the described cutting thin section analysis could be corrected. The caliper log was evaluated for breakouts either caused by the drill head, fractures or argillaceous layers, and was further correlated to the fracture description of the thin sections and the temperature log. This correlation showed possible flow path ways at two fracture zones at GT1 in the Upper Jurassic reservoir. Further, there are three wider zones with calcite cement filled fractures and recrystallised limestone, as well as slight increases in the resistivity log (Fig. 10).

The thin section analysis indicates a recurrent development of geological layers and single fractured zones at GT1, but a low occurrence of fractures in GT1a. Consequently, GT1 was influenced by the main fault zone with permeable and non-permeable fractures, whereas GT1a was unaffected by the fault zone and shows no possible flow pathways at fractures. The carbonate rocks of GT1 and GT1a were additionally dolomitised, silicified and calcified during the diagenesis at Mauerstetten. The processes such as dolomitisation, silification, and calcification of limestones could have occurred together predominantly in areas with a high density of stylolites and fractures. Therefore, it can be assumed that the dolomite, quartz or calcite crystals precipitated in areas where a high migration of $\mathrm{Mg}$-, $\mathrm{Si}$ - or Ca-rich fluids due to a higher permeability was possible. This existence of high porosity could be determined due to tectonically induced fractures visible in the caliper $\log$ and resistivity $\log$, and by coarse-grained calcite crystals. Tectonic tensile and compressional stresses caused macroscopic and microscopic fractures, as well as stylolites during foreland basin formation. To a minor degree, the migration of fluids was possible in the low porosity carbonates, consequently fluid flow depended strongly on the later tectonically induced porosity at the project site.

This secondary induced porosity by fractures was afterwards reduced by precipitation of the now visible coarsegrained crystal cements in thin sections. The dolomitisation process could have caused a volume reduction of $13 \%$, resulting in an increase in porosity (Böhm et al. 2011, Tucker $\&$ Wright 1990). However, a porosity increase is not visible within the cuttings, as the dolomite crystals developed mainly in the micritic matrix as a replacive dolomite or as a dense dolostone. The dolomite crystals vary in size between $40 \mu \mathrm{m}$ and $145 \mu \mathrm{m}$ at the site Mauerstetten, but are bigger in GT1 than in GT1a due to a possible higher migration of pore fluids. The silification and calcification resulted in a porosity decrease as minerals precipitated from the fluids in open spaces (pores, fractures) or by a neomorphism, as ghost structures are preserved. The fractures are partly or completely filled by precipitated sparry calcite cement at the site Mauerstetten and therefore, the secondary porosity was reduced. Further, all organisms were calcified and silica of the siliceous sponges migrated to other areas and precipitated in concretions. Some cuttings show quartz crystals with black crusts, possibly originating from Cretaceous karst fillings and a migration of hydrocarbons (Wolfgramm et al. 2012).

The relation between the tectonically induced stylolites (pressure solution) and fractures, and the above named diagenetic processes indicate a post-depositional dolomitisation and silification, as described by Liedmann (1992) and Reinhold (1996).

\subsection{Implication of possible flow pathways at GT1 and GT1a}

In GT1 possible flow pathways were indicated by excursions in the temperature $\log$ which are related to open or partly open fractures, although they do not provide the necessary flow zones to reach an economic level. Since the depositionally (primary) and diagenetically (secondary) induced porosity by recrystallisation processes is low, fractures are the only possible flow paths. However, the calcite filling of these fractures impairs porosity and permeability, and hence lower the reservoir quality significantly at the prospect Mauerstetten. Consequently, the Mauerstetten wells show a strong dependency on the fault zone and a low matrix porosity, which are important parameters for a successful production of deep geothermal energy. Other successful geothermal wells in the Molasse Basin are drilled into the massive or reef detritus facies of the Upper Jurassic, associated with high porosity or strong karstification (Birner et al. 2012, Böhm et al. 2011). The general pattern of the facies distribution follows a pattern with reefal carbonates and associated high porosity in the central and eastern part of the Molasse Basin while the western part is described as low porous marly carbonate basin (Meyer \& Schmidt-Kaler 1989, Birner et al. 2012). However, the reef detritus found in the drill cuttings from the Mauerstetten well indicates massive facies as well for the western part of the Bavarian Molasse Basin. This reef detritus may originate from patch reefs and should lead to high flow rates as observed in the central and eastern basin part. Compared with highly productive geothermal wells, the Upper Jurassic reservoir is more than $100 \mathrm{~m}$ deeper at the Mauerstetten site than in the central or eastern basin part and closer to the Alpine frontal fault. The low flow rates, low porosity, massive facies and deeper reservoir situation may indicate an influence of compaction and diagenesis as major controlling factors for reservoir permeability. A detailed study of the facies types, diagenesis and reservoir depth based on the systematic micro-facial analysis of numerous wells across the South German Molasse Basin has been performed by Mraz et al. (2018, submitted) and may provide a better understanding of reservoir productivity from the Upper Jurassic. 


\section{Slip magnitude, fault zonation and permeability structure}

The permeability structure of fault zones is directly related to the hydraulic properties and dimensioning of fault core and damage zone compared with the host rock (Knott et al. 1996, Agosta et al. 2007). The fault core contains the major slip surface while the damage zone flanks the core as a zone of higher fracture density and secondary or parasitic faults (Chester et al. 1993, Caine et al. 1996, Agosta \& Aydin 2006). The width of the damage zone and the fault core is directly related to the fault throw: regardless of the absolute fault throw and rock type, faults with a large throw exceeding $60 \mathrm{~m}$ have a damage zone thickness between 50 and $100 \mathrm{~m}$ with larger thickness in the hanging wall than in the footwall of normal faults (Friedman \& Wiltschko 1992, Agosta \& Aydin 2006, Savage \& Brodsky 2011, Johri et al. 2014, Choi et al. 2016). The fault core thickness has a power-law trend with an exponent 0.5 in carbonate rock when the fault throw is larger than $10 \mathrm{~m}$ (Bastesen et al. 2013). Referring to the maximum throw of the Mauerstetten fault ranging between 192 and $266 \mathrm{~m}$, the damage zone thickness is assumed as up to $100 \mathrm{~m}$ thick while the fault core is up to $15 \mathrm{~m}$ thick in the carbonate rock of the Upper Jurassic where the slip rates accumulate to the maximum fault throw. The thickness of fault core and damage zone might be smaller in the Cenozoic sections where the fault throw has a lower magnitude. The variation of the fault throw in the different seismic sections indicates a segmented fault with different activation time-intervals of displacement rather than one coherent fault surface as mapped by the seismic interpretation. The inaccuracy in the measurements of the fault throws in the seismic profiles might be another reason for the variation of fault throw magnitudes. The trend, however, shows an absolute normal faulting throw of about $230 \mathrm{~m} \pm 30 \mathrm{~m}$.

The number of small or large events on fossil faults might affect the fracture density within the damage zone and can be estimated from the relationship between co-seismic slip values, rupture length and earthquake magnitudes that is relatively well known (Wells \& Coppersmith 1994, Michetti et al. 1996, Mohammadioun \& Serva 2001). For example, a $15-20 \mathrm{~km}$ long normal fault segment with a fault throw of about $1 \mathrm{~m}$ would produce an earthquake of Ms 6.5-6.9 (Roberts et al. 2004 and references therein). The $17 \mathrm{~km}$ long Granada Fault in Spain known as an active normal fault has a throw of $300 \mathrm{~m}$ with vertical palaeo-slips of 5-7 cm per event generating earthquakes of $\leq$ Ms 5.1 in $5 \mathrm{~km}$ depth (Azanon et al. 2009). Considering also co-seismic slip and possibly compaction effects we assume several hundreds of events accumulating to the fault throw along the Mauerstetten fault. Each event may have increased the fracture density in the damage zone and might have generated more parasitic synthetic faults which may enhance the fracture porosity when the fractures are open or reduce the fracture porosity when the fractures are sealed with calcite.

The hydraulic properties of the fault zone can be estimated from the well tests and the geologic profiles of the well GT1 and the sidetrack GT1a. The well GT1 has a mini- mum distance of about $170 \mathrm{~m}$ to the mapped major fault surface in the 3D geological model while GT1a has a distance of about $340 \mathrm{~m}$ to the main fault. The estimated flow rate from GT1 is below $10 \mathrm{l} / \mathrm{sec}$ according to the well report (Geotec 2010). However, injection tests always open fractures to a larger extent than under production conditions resulting in smaller flow rates. The injection fluid contained an acid pill of $\mathrm{HCl}$ to get better access to the reservoir which produced $\mathrm{H}_{2} \mathrm{~S}$ from reaction with pyrite in the reservoir formation indicating an organic matter rich carbonate rock. GT1a provided a flow rate below $31 / \mathrm{sec}$ according to the well report (Geotec 2010). The well GT1 is located closer to the major normal fault and transects possibly synthetic minor faults (Figs. 9 and 10), which cause a flow rate that is possibly higher than in the side track GT1a. Another reason for the higher flow rate derived from GT1 is that the injectivity can be three to five times higher than the productivity due to poro-elastic effects (Grant \& Bixley 2011). Garg \& Comb (1997) suggest a 1:1 ratio of productivity to injectivity, and assuming the linear relationship of injectivity to productivity GT1 is significantly more productive than GT1a. The sidetrack GT1a is located out of the damage zone and is influenced by the matrix permeability of the host rock rather than the fracture permeability of the damage zone. The multiple phases of normal faulting may have generated a fault damage zone with higher fracture density and with a positive effect on the permeability of the fault core and fault damage zone. Obviously this fault preserved its dilative character as an inherited fossil structure in the recent compressional stress field due to local extension and lithospheric bending in the Upper Eocene to Lower Miocene with possibly positive effects on its hydraulic properties in the damage zone containing parasitic synthetic normal faults indicated by the geologic profile of the well.

Since no image logs and only the caliper log and the thin section descriptions were available from the well, suggestions can be drawn to fracture characteristics in fault core and damage zone. Calcite mineralisation in cuttings indicated healed fractures or slip planes acting as fluid barriers. No breccia is reported from cuttings as one would expect from drilling along a multiphase normal fault zone. One reason might be that the spatial relationship between fault and borehole is not accurately defined because the fault geometry is mapped from 2D seismic profiles instead of a 3D seismic survey, and by the truncated lithological layers. A 3D seismic survey might deliver a modified structural pattern with rather a segmented normal fault than one coherent fault surface. A fault stress analysis as done by Budach et al. (2017) could be performed on a fault pattern from 3D seismic data where the higher accuracy level of fault geometries allows reliable fault stress calculations. The fault pattern from 2D seismic interpretation provides a fault geometry suitable for a general fault throw analysis along the 2D seismic lines and a general slip tendency analysis for the reservoir depth, however no slip tendency analysis of individual fault surfaces. 


\section{Implication for geothermal exploration}

Polyphase normal faulting activity might have a positive impact on the growth of fracture density and damage zone width and hence the hydraulic properties of the Mauerstetten fault, which is of interest for geothermal exploration in the Bavarian Molasse Basin. However, in this particular case the fault segment at the Mauerstetten well GT1 underwent presumably three different Mesozoic deformation phases from normal to strike-slip faulting causing possibly fault gouge, pressure solution and calcite and dolomite precipitates in pore space that reduced porosity and permeability. The assumed age of the Mauerstetten fault is Upper Jurassic to Miocene based on the 2D seismic line interpretation. With a higher precision of fault and reflector geometries from 3D seismic data the fault age could be further determined. The well site GT1 is located on a promising NE-SW striking segment of an E-W striking normal fault, suggesting high fluid flow on an optimally oriented fault in the current stress field (Barton et al. 1995) but for the Mesozoic time the geodynamic history is little favourable to expect economic flow rates in the specific segment at Mauerstetten. According to the fault classification of Agemar et al. (2017) the characteristics of the Mauerstetten fault (position in the current stress field, fault geometry, age of the fault) indicate a low quality or productivity of the fault. However, compared to productive fault zones in the Bavarian Molasse Basin, the Mauerstetten fault does not differ significantly. Compared with the regional Markt Schwaben fault zone, located east of Munich, and its extension to the Munich area, the Mauerstetten fault exhibits similar characteristics such as activity until the Middle to Upper Tertiary, strike about ENE-WSW, dip towards south and a segmentation through relay ramps. According to Agemar et al. (2017) the Markt Schwaben fault should be a low productive fault, but belongs to the high productivity faults where the geothermal wells of Poing and Aschheim are located. Obviously the geometry, age and activity of faults are not the only controlling factor for reservoir porosity and permeability, as the facies of the host rock as well as compaction and diagenesis may contribute more to productivity of the Upper Jurassic reservoir than hitherto expected.

Fluid flow in carbonate rock is, however, not only fracture controlled but is affected by a complex interplay between deposition (facies), early and late stage alteration by diagenesis, hydrology including dissolution and karst, and tectonic overprint including healing of fractures. The challenges in carbonate reservoir exploration are associated with a complexity of multi-scale porosity and permeability distribution related to a wide range of biosediments on the carbonate platform (Ahr 2008). Geothermal exploration has shown that highest recovery from the Upper Jurassic aquifer in the Bavarian Molasse Basin is from reef detritus limestone of the prolific and highly bio-diversified carbonate factory of the carbonate platform (Böhm et al. 2011). In contrast, the low-diversity carbonate factory dominated by algae-microbial associations is less prospective (Ahr 2008). According to the cutting analyses of the Mauerstetten wells, the depositional environment was located in the latter facies type ex- hibiting a minor degree on dolomitisation, dissolution and fractures. Dolomitisation and karstification seems to be related to fractures at Mauerstetten. However, mechanisms on facies-selective, fabric-selective, texture-selective and facies-selective porosity and permeability development or pore space structure are yet not fully understood for the Upper Jurassic of the Molasse Basin.

The cutting material from the well GT1 with sidetrack GT1a indicates a very low matrix porosity in tight limestone with only matrix dolomite. The low flow rate from GT1 is therefore attributed to fractures indicating a fracture-dominated reservoir. The polyphase activity of the normal fault may have a positive impact on the fracture density, however the low recovery might be related to poorly connected fractures, sealed fractures and/or low intercrystalline porosity in the limestone. Fracture porosity scale is not only related to fracture spacing, width and length but also to the area size or reservoir thickness and interconnectivity of the fractures (Ahr 2008, Youn \& Gutierrez 2011). The latter could be the critical factor for the Mauerstetten fault. Only synthetic normal faults are identified by the lithologic profile of the well and the 2D seismic sections. Mapped fractures and parasitic faults are parallel and may undulate in strike possibly generating steep or vertical intersection lines that could channel fluids. A higher degree in interconnectivity is, however, given by an array of synthetic and antithetic fractures that are typically generated in graben situations or along listric normal faults. Intersection lines of syn- and antithetic fractures or crossing normal faults are developed laterally and provide optimal channels for fluid flow (Ferrill et al. 2009). Transferred to reservoir depth, these channels might be kept open even in a compressional stress field. Along the Mauerstetten well only synthetic fractures are observed thus no lateral fluid channels can be expected with reduced fracture-assisted permeability and resulting low flow rate from the well GT1.

Reservoir productivity cannot be simply attributed to fast communication along faults cutting the top of the reservoir. However, faults are a structural element that can be reliably detected through reflection seismic before drilling while diagenetic and depositional heterogeneities can only be identified after drilling and extensive well $\log$ - core analysis seismic data correlation of a minimum of 20 wells in a $20 \mathrm{~km}^{2}$ reservoir block (Spina et al. 2014). Before the 3D stratigraphic and sequential architecture of a carbonate platform can be simulated from information of a number of wells and 3D seismic data, identifiable seismic-scale faults may play a primary role in targeting of geothermal wells in a new prospect (e.g. Budach et al. 2017). The stratigraphy-related fault throw analysis may help to select favourable faults bearing fluids from a complex fault pattern for the following reasons:

- Fault segments with an initial offset in the Upper Mesozoic/Lower Cenozoic were generated when the Jurassic carbonate platform was exposed to a terrestrial environment during marine regression phases. Faulting activity during a regression phase may have enhanced the karstification process along these faults, hence increased the permeability of these fault segments. At Mauerstetten, karstification was not documented within the cuttings, 
still it can be assumed at the main fault zone which was possibly affected by karstification during the Cretaceous.

- Fault segments that were active as normal faults during Jurassic rifting are NE-SW striking fault segments possibly reactivated as reverse fault during the early Cretaceous, as strike-slip fault in the late Cretaceous hiatus, and from Oligocene (and possibly Eocene) until the Middle Miocene (Burdigalian) as normal fault. In particular the $\mathrm{E}-\mathrm{W}$ trending fault segments preserved their dilative character in an evolving contractional stress regime. Dilational zones are known to significantly enhance fluid flow (Ferrill \& Morris 2003) with an elevated permeability compared to the intact rock (Knott et al. 1996).

- The increased permeability structure of faults that were active from Late Mesozoic to Middle Miocene might have channelled a higher amount of dolomitising (i.e. $\mathrm{Mg}^{2+}$ bearing) fluids creating fault-related dolomites with elevated porosity (Smith 2006). The formation of faultrelated dolomite geobodies during normal faulting is known from carbonate reservoirs, the generation of additional pore space through dolomitisation, however, may be prevented by hydrothermal fluids and related pore filling with dolomite or calcite cements (Vandeginste et al. 2013).

- Faults of graben structures are assumed as preferred settings of lateral flow because of the presence of synthetic and antithetic fractures and crossing normal faults generating lateral intersection lines that serve as fluid channels (Ferril et al. 2009). Fault damage zones are accumulate syn- and antithetic fractures flanking the faults of grabens but are detected in the seismic study only in the Mesozoic cover-rocks and in the basement.

At the Unterhaching site, the fault throw analysis was conducted as well (Budach et al. 2017) revealing an episodically active transtensional fault zone with crossing normal faults. The fracture pattern formed by this episodic reactivation is assumed to increase the hydraulic conductivity of the fault zone hence the productivity of the wells at the Unterhaching site. This detailed fault throw analysis can be conducted if 3D seismic data are available and the study of Budach at al. (2017) underlines the importance of 3D seismic surveys for geothermal exploration. Two further project sites with deep wells comparable to Mauerstetten were realised at the locations Weilheim and Geretsried. Both projects represent targets in the deep Upper Jurassic of the Bavarian Molasse Basin. The wells are not economically productive, however detailed results from these wells are not published yet and the causes for the lacking productivity are not clear so far. Provided the publication of drilling seismic interpretation results from these sites, a systematic comparison between Mauerstetten, Weilheim and Geretsried would provide a better understanding of geological controls on reservoir productivity from the deep basin part.

\section{Conclusion}

Individual phases of normal faulting can be identified with a stratigraphy-related fault throw analysis on 2D seismic sections. Multiphase fossil normal faults are detected with this approach in the Bavarian Molasse Basin. The faulting regime of the $\mathrm{E}-\mathrm{W}$ trending faults is inconsistent with the compressive present-day stress field indicating fossil normal faults. The correlation of the quantitative fault expansion index (QFEI) with the regional tectonic events in the Alpine foreland allows a further characterisation of faults as permeability anisotropies in carbonate rock of the Molasse Basin. Depending on strike and dip azimuth, fault segments exhibit a different kinematic evolution. While E-W oriented segments underwent a multiphase normal faulting history from Jurassic to Miocene due to rifting in the Helvetic-European shelf and subsequent lithospheric bending in the foreland of the evolving orogeny during Alpine nappe thrusting, NESW trending fault segments that originated as Jurassic normal faults presumably were reactivated first as normal faults in the Lower Cretaceous and as strike-slip faults in the Upper Cretaceous due to subduction in the Valais ocean (e.g. Stampfli 1992). The culmination of normal faulting was in the Lower Oligocene obviously related to lithospheric bending associated with the lithospheric load of the Alpine foldthrust belt. Normal faulting continued on the Mauerstetten fault to Miocene and died out in the Burdigalian.

With their heterogeneity caused by deposition, biogenic content, diagenetic alteration and facies-selective fracture pattern carbonate rocks belong to the most challenging reservoir types. Predicting fault attributes in subsurface carbonate reservoirs require fault zone drilling and reservoir diagnostics through pore space evaluation in particular from drill cores analysis to identify chemical, mechanical, biological or depositional processes affecting porosity, permeability and flow units.

Hydraulic well test data from the Mauerstetten well that is placed into the fault zone and a sidetrack placed off the fault zone in carbonate host rock indicate a higher permeability in the fault damage zone (GT1) compared to the host rock (GT1a). The distance of the side track to the fault zone is $340 \mathrm{~m}$ and may explain the very low flow rate of $<3 \mathrm{l} / \mathrm{sec}$. The flow rate of the main well placed into the fault zone is estimated with $10 \mathrm{l} / \mathrm{sec}$, however the steady state was not reached. The flow rate from the host rock is around three times lower than from the fault damage zone, indicating lowpermeable host rock according to the well report (Geotec 2010). The flow might have been higher if the reservoir rock had a higher porosity. However, the NE-SW fault segment drilled by the Mauerstetten well GT1 underwent a multiphase faulting activity from normal to strike-slip faulting in the Mesozoic with possible fault gouge generation and fracture healing processes which reduced the fault and primary host rock permeability. Different processes may occur when NE-SW or NW-SE faults are generated in the Cenozoic as young strike-slip fault under a compressional stress field with a SH direction in N-S. These conjugate strike-slip faults may act as preferential fluid flow zones in the current stress 
field due to interconnecting Riedel shears in the fault damage zone (Moeck et al. 2007).

The damage zone of multiple phase normal faults may be thicker than of single-phase normal faults. The thickness of the damage zone of the dominating normal fault in the Mauerstetten geothermal prospect is estimated at $100 \mathrm{~m}$ based from the fault throw of $230 \mathrm{~m} \pm 30 \mathrm{~m}$ and from descriptions of worldwide case studies. More fault zone drilling in carbonate rock is necessary to describe, quantify and understand the relationship between kinematic history of faults, their permeability structure, fault zone dimensioning and influences from facies and diagenesis.

Fossil content is arguably more important for interpreting depositional environment in carbonates than in sandstones because most carbonates form in marine environment where fossil assemblages can reveal subtle differences in depositional settings. The case study of Mauerstetten shows similarities to the Franconian facies, but not a highly porous matrix. This indicates a low permeable reservoir and explains the low flow rate from the well GT1. Faults and optimally developed thick damage zones do not assist porosity, and permeability if the depositional or diagenetic reservoir does not contain porosity. However, technological treatments and reservoir engineering may help to develop sites as Mauerstetten. Reservoir engineering can only be developed for carbonate reservoirs if the depositional, diagenetic and tectonic history and its impact on pore space, permeability distribution and the overall fluid-rock system are identified.

\section{Acknowledgements}

Thank is given to Exorka for data release. The 2D seismic is interpreted with PETREL software (Schlumberger), the visualisation and analysis of 3D geological model is improved by earthVision (Dynamic Graphics). Furthermore the authors gratefully acknowledge the thorough review of Ingma Budach and an anonymous reviewer.

\section{References}

Agemar, T., Hese, F., Moeck, I. \& Stober, I. (2017): Kriterienkatalog für die Erfassung tiefreichender Störungen und ihrer geothermischen Nutzbarkeit in Deutschland. - Z. Dt. Ges. Geowiss., 168 (2): 285-300.

Agosta, F. \& Aydin, A. (2006): Architecture and deformation mechanism of basin-bounding normal fault in Mesozoic platform carbonates, central, Italy. - J. Struct. Geol., 28: 1445-1467.

Agosta, F., Prasad, M. \& Aydin, A. (2007): Physical properties of carbonate fault rocks, fucino basin (Central Italy): implications for fault seal in platform carbonates. - Geofluids, 7 (1): 19-32.

Ahr, W.M. (2008): Geology of carbonate reservoirs: 277 p., Hoboken, New Jersey (Wiley).

Allen, P.A., Homewood, P. \& Williams, G.D. (1986): Foreland basins: an introduction. - In: Allen, P.A. \& Homewood, P. (ed): Foreland basins. - Spec. Publ. Int. Assoc. Sedimentol., 8: 3-12.
Anderson, E.M. (1951): The dynamics of faulting and dyke formation with applications to Britain: 206 p., Edinburgh (Oliver \& Boyd).

Azanon, J.M., Garcia-Mayordomo, J., Insua-Arevalo, J.M. \& Rodrigues-Peces, M.J. (2009): Paleoseismological features of the Granada Fault. - $1^{\text {st }}$ INQUA-IGCP-567 International Workshop on Earthquake Archeology and Paleoseismology, Proceedings: $1-3$.

Bachmann, G.H. \& Mueller, M. (1992): Sedimentary and structural evolution of the German Molasse Basin. - Eclogae Geol. Helv., 85 (3): 519-530.

Bachmann, G.H., Dohr, G. \& Mueller, M. (1982): Exploration in a classic thrust belt and its foreland: Bavarian Alps, Germany. AAPG Bull., 66: 2529-2542.

Bachmann, G.H., Mueller, M. \& Weggen, K. (1987): Evolution of the Molasse Basin (Germany, Switzerland). - Tectonophysics, 137: 77-92.

Barnikel, F. \& Geiss, E. (2008): The BASE Project - An opensource catalogue for earthquakes in Bavaria, Germany. - Natural Hazards Earth Syst. Sci., 8: 1395-1401.

Bartels, J., Wenderoth, F., Fritzer, T., Huber, B., Dussel, M., Lüschen, E., Thomas, R. \& Schulz, R. (2012): A new simulation model to evaluate interaction between neighbouring hydrogeothermal installations developing the deep Malm aquifer in the Munich region. - Geophys. Res. Abstr., 14, EGU 2012 9157.

Barton, C.A., Zoback, M.D. \& Moos, D. (1995): Fluid flow along potentially active faults in crystalline rock. - Geology, 23 (8): 683-686.

Bastesen, E., Braathen, A. \& Skar, T. (2013): Comparison of scaling relationships of extensional fault cores in tight carbonate and porous sandstone reservoirs. - Petroleum Geosci., 19: 385398.

Bayerischer Geothermieatlas (2010): Bayerischer Geothermieatlas - Hydrothermale Energiegewinnung: 93 p., München (Bayer. Staatsministerium für Wirtschaft, Infrastruktur, Verkehr und Technologie).

Birner, J., Mayr, C., Thomas, L., Schneider, M., Baumann, T. \& Winkler, A. (2011): Hydrochemistry and evolution of deep groundwaters in the Malm aquifer of the Bavarian part of the South German Molasse Basin. - Z. Geol. Wiss., 39 (3/4): 291308.

Birner, J., Fritzer, T., Jodocy, M., Savvatis, A., Schneider, M. \& Stober, I. (2012): Hydraulische Eigenschaften des Malmaquifers im Süddeutschen Molassebecken und ihre Bedeutung für die geothermische Erschließung. - Z. Geol. Wiss., 40: 133-156.

Böhm, F., Birner, J., Steiner, U., Koch, R., Sobott, R., Schneider, M. \& Wang, A. (2011): Tafelbankiger Dolomit in der Kernbohrung Moosburg SC4: Ein Schlüssel zum Verständnis der Zuflussraten in Geothermiebohrungen des Malmaquifers (Östliches Molasse-Becken, Malm $\delta-\zeta$; Süddeutschland). - Z. Geol. Wiss., 39 (2): 117-157.

Bradley, D.C. \& Kidd, W.S.F. (1991): Flexural extension of the upper continental crust in collisional foredeeps. - Geol. Soc. Am., Bull., 103: 1416-1438.

Bry, M., White, N., Singh, S., England, R. \& Trowell, C. (2004): Anatomy and formation of oblique continental collision: South Falkland basin. -Tectonics, 23, TC4011: 1-20.

Budach, I., Moeck, I., Lüschen, E. \& Wolfgramm, M. (2017): Temporal evolution of fault systems in the Upper Jurassic of the Central German Molasse Basin: case study Unterhaching. - Int. J. Earth Sci., 107 (2); DOI: doi.org/10.1007/s00531-017-1518-1. 
Cacace, M., Bloecher, G., Watanabe, N., Moeck, I., Boersing, N., Scheck-Wenderoth, M., Kolditz, O. \& Huenges, E. (2013): Modelling of fractured carbonate reservoirs: outline of a novel technique via a case study from the Molasse Basin, southern Bavaria, Germany. - Environ. Earth Sci. 70 (8): 3585-3602.

Caine, J.S., Evans, J.P. \& Forster, C.B. (1996): Fault zone architecture and permeability structure. - Geology, 24: 1025-1028.

Chester, F.M., Evans, J.P. \& Biegel, R.L. (1993): Internal structure and weakening mechanisms of the San Andreas faults. - J. Geophys. Res., 98: 771-786.

Choi, J.-H., Edwards, P., Ko, K. \& Kim, Y.-S. (2016): Definition and classification of fault damage zones: a review and a new methodological approach. - Earth-Sci. Rev., 152: 70-87.

Colins de Tarsienne, E., Niederbacher, P. \& Winkler, G. (1987): Geologisch-geophysikalische Grundlagen der Kohlenwasserstoff-Exploration in Vorarlberg. - In: Bergbau im Wandel, Leobener Bergmannstag 1987: 681-687, Graz / Essen (Akad. Druck- u. Verlagsanstalt / Verlag Glückauf Essen).

Correia, M.G., Maschio, C., Schiozer, D.J. \& dos Santos, M.S. (2011): Sensitivity analysis for dual porosity and dual permeability systems to small and large scale heterogeneities in a naturally fractured carbonate reservoir. - SPE Brasil Offshore Conference \& Exhibition, 14-17 June 2011, Macae, Brazil, SPE paper 143149: 1-7.

Dercourt, J., Zonenshain, L.P., Ricou, L.E., Kazmin, V.G., le Pichon, X., Knipper, A.L., Grandjacquet, C., Sbortshikov, I.M., Geyssant, J., Lepvrier, C., Pechersky, D.H., Boulin, J., Sibuet, J.C., Savostin, L.A., Sorokhtin, O., Westphal, M., Bazhenov, M.L., Lauer, J.P. \& Biju-Duval, B. (1986): Geological evolution of the Tethys belt from the Atlantic to the Pamirs since the Lias. - Tectonophysics, 123: 241-315.

Dercourt, J., Ricou, L.E. \& Vrielynck, B. (ed.) (1993): Atlas Tethys palaeoenvironmental maps: 307 p., Paris (Gauthier-Villars).

Dunham, R.J. (1962): Classification of carbonate rocks according to depositional textures. - In: Ham, W.E. (ed): Classification of carbonate rocks - A symposium. - AAPG Mem., 1: 108-121.

Ferrill, D.A. \& Morris, A.P. (2003): Dilational normal faults. - J. Struct. Geol., 25: 183-196.

Ferrill, D.A., Morris, A.P. \& McGinnis, R.N. (2009): Crossing normal faults in field exposures and seismic data. - AAPG Bull., 95 (11): 1471-1488.

Flügel, E. (2010): Microfacies of carbonate rocks - Analysis, interpretation and application; $2^{\text {nd }}$ ed.: 984 p., Berlin (Springer).

Folk, R.L. (1959): Practical petrographic classification of limestones. - AAPG Bull., 43: 1-38.

Frank, W. (1987): Evolution of the Austroalpine elements in the Cretaceous. - In: Flügel, H.W. \& Faupl, P. (ed.): Geodynamics of the Eastern Alps: 377-406, Wien (Deuticke).

Friedman, M. \& Wiltschko, D.V. (1992): An approach to exploration for naturally fractured reservoirs. - In: Schmoker, J.W., Coalson, E.B. \& Brown, C.A. (ed.): Geological studies relevant to horizontal drilling: examples from western North America. - Rocky Mountain Association of Geologists: 89-99.

Garg, S.K. \& Combs, J. (1997): Use of slim holes with liquid feedzones for geothermal reservoir assessment. - Geothermics, 26 (2): 153-178.

Geotec (2010): Mauerstetteen GT1 and GT1a. - Technischer Abschlussbericht Geotec Consult: 25 p. [unpubl.].

Grant, M.A. \& Bixley, P.F. (2011): Geothermal reservoir engineering, $2^{\text {nd }}$ ed.: 378 p., New York (Academic Pr.).

Gudmundsson, A., Fjeldskaar, I. \& Brenner, S.L. (2002): Propagation pathways and fluid transport in jointed and layered rocks in geothermal fields. - J. Volcanol. Geotherm. Res., 116: 257-278.
Hinsch, R. (2013): Laterally varying structure and kinematics of the Molasse fold and thrust belt of the Central Eastern Alps: implications for exploration. - AAPG Bull., 97: 1805-1831.

Homewood, P., Allen, P.A. \& Williams, G.D. (1986): Dynamics of the Molasse Basin of Western Switzerland. - In: Allen, P.A. \& Homewood, P. (ed.): Foreland basins. - Spec. Publ. Int. Assoc. Sedimentol., 8: 199-217.

Hsü, K.J. \& Briegel, U. (1991): Geologie der Schweiz - Ein Lehrbuch für den Einstieg, und eine Auseinandersetzung mit den Experten: 219 p., Basel (Birkhäuser).

Johri, M., Dunham, E.M., Zoback, M.D. \& Fang, Z. (2014): Predicting fault damage zones by modeling dynamic rupture propagation and comparison with field observations. - J. Geophys. Res. (Solid Earth), 119 (2): 1251-1272.

Jolie, E., Klinkmueller, M. \& Moeck, I. (2012): Diffuse degassing measurements as a geochemical exploration tool: a case study from the Brady's geothermal system (Nevada, USA). - Geotherm. Resour. Counc., Trans., 36: 685-688.

Karner, G.D. \& Watts, A.B. (1983): Gravity anomalies and flexure of the lithosphere at mountain ranges. - J. Geophys. Res., 88 (B12): 10,449-10,477.

Knott, S.D., Beach, A., Brockbank, P.J., Brown, J.L., McCallum, J.E. \& Welbon, A.I. (1996): Spatial and mechanical controls on normal fault populations. - J. Struct. Geol., 18 (2/3): 359-372.

Koch, R., Senowbari-Daryan, B. \& Strauss, H. (1994): The late Jurassic "Massenkalk Fazies" of Southern Germany: calcareous sand piles rather than organic reefs. - Facies, 31: 179-208.

Koch, R., Bachmann, G.H. \& Müller, M. (2010): Fazies des Oberen Jura (Malm) der Bohrungen Scherstetten 1 und 2 (MolasseBecken, Süddeutschland) und ihre Bedeutung für die geothermische Exploration. - Z. Geol. Wiss., 38: 327-351.

Kott, R. (1989): Fazies und Geochemie des Treuchtlinger Marmors (Unter- und Mittel-Kimmeridge, Südliche Frankenalb). - Berliner Geowiss. Abh., A 111: 115 p.

Krämer, C. (2009): Identifikation horizontaler Blattverschiebungen im Untergrund des Molassetrogs - Neue Interpretationsergebnisse auf Grundlage von 2D-Seismik. - Proc. Geothermiekongress, Bochum, Germany, 17-19 November 2009: 10 p.

Kuckelkorn, K. \& Hiltmann, W. (1985): Maturität und Erdölbildung in den Allgäuer Alpen - Organopetrographische und geochemische Untersuchungen. - In: KFA Jülich (ed.): Energieforschung und Energietechnologie, Statusreport 1985, Geotechnik und Lagerst.: 569-575.

Kuhlemann, J. \& Kempf, O. (2002): Post-Eocene evolution of the North Alpine Foreland Basin and its response to Alpine tectonics. - Sediment. Geol., 152: 45-78.

Lammerer, B., Gebrande, H., Lüschen, E. \& Veselá, P. (2008): A crustal-scale cross-section through the Tauern Window (eastern Alps) from geophysical and geological data. - In: Siegesmund, S., Fügenschuh, B. \& Froitzheim, N. (ed.): Tectonic aspects of the Alpine-Dinaride-Carpathian system. - Geol. Soc. London, Spec. Publ., 298: 219-229.

Lange, H. (1981): Die Kreide im Untergrund des Molassebeckens (Purbeck bis Campan). - In: Erläuterungen zur Geologischen Karte von Bayern 1: 500000 ( $3^{\text {rd }}$ ed.): 71-74, München (Bayer. Geol. Landesamt).

Leinfelder, R.R., Nose, M., Schmid, D.U. \& Werner, W. (1993): Microbial crusts of the Late Jurassic: Composition, palaeoecological significance and importance in reef construction. - Facies, 29: 195-230.

Leinfelder, R.R., Schmid, D.U., Nose, M. \& Werner, W. (2002): Jurassic reef patterns - The expression of a changing globe. SEPM Spec. Publ., 72: 465-520. 
Lemcke, K. (1973): Zur nachpermischen Geschichte des nördlichen Alpenvorlandes. - Geol. Bavarica, 69: 5-48.

Lemcke, K. (1976): Über tiefe Grundwässer im süddeutschen Alpenvorland. - Bull. Ver. Schweiz. Petroleum-Geol. u. -Ing., 42: 9-18.

Lemcke, K. (1977): Erdölgeologisch wichtige Vorgänge in der Geschichte des süddeutschen Alpenvorlandes. - Erdöl-Erdgas-Z., 93: 50-56.

Lemcke, K. (1988): Geologie von Bayern; Bd. 1: Das bayerische Alpenvorland vor der Eiszeit: 175 p., Stuttgart (Schweizerbart).

Lian, P.Q. \& Ma, C.Y. (2012): The characteristics of relative permeability curves in naturally fractured carbonate reservoirs. $-\mathrm{J}$. Can. Pet. Tech., 3: 137-142.

Liedmann, W. (1992): Diagenetische Entwicklung Süddeutscher Malmkarbonate (unter Berücksichtigung lumineszenzpetrographischer, fluid inclusions und geochemischer Untersuchungsmethoden). - Diss. Univ. Heidelberg: 307 p.

Loske, B. \& Witte, C. (2008): 2D seismic survey for the geothermal permit areas Mauerstetten, Marktoberdorf, Bidingen and Weilheim - Data processing and interpretation. - Final Report DMT, Exorka: 87 p. [unpubl.].

Lüschen, E., Borrini, D., Gebrande, H., Lammerer, B., Millhan, K., Neubauer, F., Nicolich, R. \& TRANSALP Working Group (2006): TRANSALP - Deep crustal Vibroseis and explosive seismic profiling in the Eastern Alps. - Tectonophysics, 414 (1/4): 9-39.

Lüschen, E., Dussel, M., Thomas, R. \& Schultz, R. (2011): 3D seismic survey for geothermal exploration at Unterhaching, Munich, Germany. - First Break, 29: 45-54.

Matter, A., Homewood, P., Caron, C., Rigassi, D., van Stuijvenberg, J., Weidmann, M. \& Winkler, W. (1980): Flysch and molasse of Western and Central Switzerland. - In: Trümpy, R. (ed.): Geology of Switzerland - A guide-book, part B: 261-293.

Meyer, R.K.F. (1994): „Moosburg 4 “, die erste Kernbohrung durch den Malm unter der bayerischen Molasse. - Erlanger Geol. Abh., 123: 51-81.

Meyer, R.K.F. \& Schmidt-Kaler, H. (1989): Paläogeographischer Atlas des süddeutschen Oberjura (Malm). - Geol. Jb., A 115: $77 \mathrm{p}$.

Meyer, R.K.F. \& Schmidt-Kaler, H. (1996): Jura. - In: Erläuterungen zur Geologischen Karte von Bayern 1: 500 000: 112-125, München (Bayer. Geol. Landesamt).

Michel, U. (1999): Gesteinsphysikalische Eigenschaften und fazielle Ausbildung der oberjurassischen Massenfazies (Kimmeridge) der südlichen Frankenalb (Stammham). - In: Seiler, K.P. (ed.): Grundwasserschutz im Karst der südlichen Frankenalb. - GSF Bericht 4/99: 48-56.

Michetti, A.M., Brunamonte, F., Serva, L. \& Vittori, E. (1996): Trench investigations of the 1915 Fucino earthquake fault scarps (Abruzzo, central Italy): Geological evidence of large historical events. - J. Geophys. Res., 101 (B3): 5921-5936; DOI: $10.1029 / 95 J B 02852$.

Moeck, I. \& Backers, T. (2011): Fault reactivation potential as critical factor during reservoir stimulation. - First Break, 29: 6774.

Moeck, I., Dussel, M., Tröger, U. \& Schandelmeier, H. (2007): Fracture networks in Jurassic carbonate rock of the Algarve Basin (South Portugal): Implications for aquifer behaviour related to the recent stress field. - In: Krasny, J. \& Sharp, J.M. (ed.): Groundwater in fractured rocks. - IAH Spec. Publ., 9: 483497.
Moeck, I., Schandelmeier, H. \& Holl, H.G. (2009a): The stress regime in Rotliegend reservoir of the Northeast German Basin. Int. J. Earth Sci., 98 (7): 1643-1654.

Moeck, I., Kwiatek, G. \& Zimmermann, G. (2009b): Slip tendency, fault reactivation potential and induced seismicity in a deep geothermal reservoir. - J. Struct. Geol., 31: 1174-1182.

Mohammadioun, B. \& Serva, L. (2001): Stress drop, slip type, earthquake magnitude and seismic hazard. - Bull. Seismol. Soc. Am., 94 (4): 694-707.

Morris, A., Ferrill, D.A. \& Henderson, D.B. (1996): Slip-tendency analysis and fault reactivation. - Geology, 24 (3): 275-278.

Müller, M. (1985): Maderhalm 1 und Kierwang 1 - Zwei Tiefbohrungen in das Helvetikum des bayerischen Allgäus. - Jb. Geol. B.-A., 127 (4): 639-641.

Mraz, E., Moeck, I., Wolfgramm, M. \& Thuro, K. (2018): Microfacies analysis in Upper Jurassic carbonates with implications for reservoir quality in the Molasse Basin. - Facies, 30 [submitted].

Nachtmann, W. \& Wagner, L. (1987): Mesozoic and Early Tertiary evolution of the Alpine Foreland in Upper Austria and Salzburg, Austria. - In: Ziegler, A. (ed.): Compressional intra-plate deformations in the Alpine Foreland. - Tectonophysics, 137 (1/4): 61-76.

Niebuhr, B. \& Pürner, T. (2014): Plattenkalk und Frankendolomit - Lithostratigraphie der Weißjura-Gruppe der Frankenalb (auBeralpiner Oberjura, Bayern). - In: Niebuhr, B. (ed.): Lithostratigraphie der Weißjura-Gruppe der Frankenalb (außeralpiner Oberjura) und der mittel- bis oberjurassischen Reliktvorkommen zwischen Straubing und Passau (Bayern) - Beitrag zur Stratigraphie von Deutschland. - Schriftenr. Dt. Ges. Geowiss., 83: 5-72.

Pfiffner, O.A. (1986): Evolution of the north Alpine foreland basin in the Central Alps. - In: Allen, P.A. \& Homewood, P. (ed.): Foreland basins. - Spec. Publ. Int. Assoc. Sedimentol., 8: 219228.

Pomoni-Papaioannou, F., Flügel, E. \& Koch, R. (1989): Depositional environments and diagenesis of Upper Jurassic subsurface sponge- and Tubiphytes reef limestones: Altensteig 1 well, Western Molasse Basin, Southern Germany. - Facies, 21: 263284.

Reinecker, J., Tingay, M., Müller, B. \& Heidbach, O. (2010): Present-day stress orientation in the Molasse Basin. - Tectonophysics, 482: 129-138.

Reinhold, C. (1996): Prozesse, Steuerung und Produkte komplexer Diagenese-Sequenzen in süddeutschen Malm-Karbonaten Die oberjurassische Massenkalk- und Bankkalkfazies bei Geislingen/Steige (Oxford/Kimmeridge, östliche Schwäbische Alb). - Diss. TU Berlin: 255 p.

Reinhold, C. (1998): Multiple episodes of dolomitization and dolomite recrystallization during shallow burial in Upper Jurassic shelf carbonates: eastern Swabian Alb, southern Germany. Sediment. Geol., 121: 71-95.

Roberts, C.W., Jachens, R.C., Ponce, D.A. \& Langenheim, V.E. (2004): Isostatic residual gravity map of the Santa Clara Valley and vicinity, California. - U.S. Geol. Surv. Open-file Report 04-1297.

Roeder, D. \& Bachmann, G.H. (1996): Evolution, structure and petroleum geology of the German Molasse Basin. - In: Ziegler, P. \& Horvath, F. (ed.): Peri-Tethys Memoir 2: structure and prospects of Alpine basins and forelands. - Mém. Mus. Nat. Hist. Natur., 170: 263-284.

Savage, H.M. \& Brodsky, E.E. (2011): Collateral damage: Evolution with displacement of fracture distribution and secondary 
fault strands in fault damage zones. - J. Geophys. Res., 116 (14); DOI: 10.1029/2010JB007665.

Schmid, S.M., Pfiffner, O.A., Froitzheim, N., Schönborn, G. \& Kissling, E. (1996): Geophysical-geological transect and tectonic evolution of the Swiss-Italian Alps. - Tectonics, 15 (5): 1036-1064.

Schmid, S.M., Fügenschuh, B., Kissling, E. \& Schuster, R. (2004): Tectonic map and overall architecture of the Alpine orogen. Eclogae Geol. Helv., 97 (1): 93-117.

Schmid, S.M., Bernoulli, D., Fügenschuh, B., Matenco, L., Schefer, S., Schuster, R., Tischler, M., Ustaszewski, K. (2008): The Alpine-Carpathian-Dinaridic orogenic system: correlation and evolution of tectonic units. - Swiss J. Geosci., 101: 139-183.

Schneider, J. (1962): Der Jura in Erdölbohrungen des westlichen Molassetroges. - In: Geyer, O.F. (ed.): Hermann-AldingerFestschrift: 163-172, Stuttgart (Schweizerbart).

Scholz, H. (1995): Bau und Werden der Allgäuer Landschaft. Zwischen Lech und Bodensee. Eine süddeutsche Erd- und Landschaftsgeschichte; $2^{\text {nd }}$ ed.: 305 p., Stuttgart (Schweizerbart).

Seiler, K. (1999): Grundwasserschutz im Karst der südlichen Frankenalb. - GSF-Bericht, 4: 123 p.

Sibley, D.F. \& Gregg, J.M. (1987): Classification of dolomite rock textures. - J. Sediment. Res., 57: 967-975.

Sissingh, W. (1997): Tectonostratigraphy of the North Alpine Foreland Basin: Correlation of the Tertiary depositional cycles and orogenic phases. - Tectonophysics, 282: 223-256.

Smith, L.B. Jr (2006): Origin and reservoir characteristics of Upper Ordovician Trenton-Black River hydrothermal dolomite reservoirs in New York. - AAPG Bull., 90: 1696-1718.

Spina, V., Borgomano, J., Nely, G., Shuchukina, N., Irving, A., Neumann, C. \& Neillo, V. (2014): The evolution of the Kharyaga carbonate platform during the Devonian - Carbonate response to the structural heritage. - Proc. $76^{\text {th }}$ EAGE Conference \& Exhibition, 16-19 June 2014, Amsterdam: 5 p.

Stampfli, G. (1992): Exotic terranes in the Alps, the Briançonnais domain as an example. - Abstr. 29 $9^{\text {th }}$ Int. Geol. Congr., Kyoto: 123.

Stampfli, G.M. \& Borel, G. (2004): The TRANSMED transects in space and time: Constraints on the paleotectonic evolution of the Mediterranean domain. - In: Cavazza, W., Roure, F.M.,
Spakman, W., Stampfli, G.M. \& Ziegler, P.A. (ed.): The TRANSMED atlas: The Mediterranean region from crust to mantle: 53-80, Berlin (Springer).

Stober, I., Wolfgramm, M. \& Birner, J. (2013/14): Hydrochemie der Tiefenwässer in Deutschland. - Z. Geol. Wiss., 41-42 (5/6): 339-380.

TRANSALP Working Group (2002): First deep seismic reflection images of the Eastern Alps reveal giant crustal wedges and transcrustal ramps. - Geophys. Res. Lett., 29; DOI: 10.1029/ 2002GL014911.

Trümpy, R. (1988): A possible Jurassic Cretaceous transform system in the Alps and Carpathians. - Geol. Soc. Am., Spec. Pap., 218: 93-109.

Tucker, M.E. \& Wright, V.P. (1990): Carbonate sedimentology: 482 p., Oxford (Blackwell).

Tvedt, A.B.M., Rotevatn, A., Jackson, C.A.-L., Fossen, H. \& Gawthorpe, R.L. (2013): Growth of normal faults in multilayer sequences: A 3D seismic case study from the Egersund Basin, Norwegian North Sea. - J. Struct. Geol., 55: 1-20.

Vandeginste, V., John, C.M., van der Flierdt, T. \& Cosgrove, J.W. (2013): Linking process, dimension, texture, and geochemistry in dolomite geobodies: A case study from Wadi Mistal (northern Oman). - AAPG Bull., 97 (7): 1181-1207.

Wells, D.L. \& Coppersmith, K.J. (1994): New empirical relationships among magnitude, rupture length, rupture width, rupture area, and surface displacement. - Bull. Seismol. Soc. Am., 84 (4): 974-1002.

Wolfgramm, M., Dussel, M., Lüschen, E., Schulz, R., Rüdiger, T. \& Koch, R. (2012): Zuflusszonen im Malm - Untersuchungen des geothermischen Hauptgrundwasserleiters im süddeutschen Molassebecken. - bbr Sonderh. Geothermie: 75-82.

Youn, D. \& Gutierrez, M. (2011): Effect of fracture distribution on permeability of fractured rock masses. $-45^{\text {th }}$ US Rock Mechanics/Geomechanics Symp., San Francisco, June 26-29, 2011, ARMA paper 11-329: $7 \mathrm{p}$.

Manuscript received: 04.07.2018

Revisions required: 18.07.2018

Revised version received: 16.08 .2018

Accepted for publication: 17.08.2018 